\title{
MECHANISMS IN ENDOCRINOLOGY Estradiol as a male hormone
}

\author{
Nicholas Russell1,2 and Mathis Grossmann ${ }^{1,2}$ \\ 'Department of Medicine Austin Health, University of Melbourne, Heidelberg, Victoria, Australia and ${ }^{2}$ Department of \\ Endocrinology, Austin Health, Heidelberg, Victoria, Australia
}

Correspondence

should be addressed

to M Grossmann

Email

mathisg@unimelb.edu.au

\begin{abstract}
Evidence has been accumulating that, in men, some of the biological actions traditionally attributed to testosterone acting via the androgen receptor may in fact be dependent on its aromatization to estradiol (E2). In men, E2 circulates at concentrations exceeding those of postmenopausal women, and estrogen receptors are expressed in many male reproductive and somatic tissues. Human studies contributing evidence for the role of E2 in men comprise rare case reports of men lacking aromatase or a functional estrogen receptor alpha, short-term experiments manipulating sex steroid milieu in healthy men, men with organic hypogonadism or men with prostate cancer treated with androgen deprivation therapy (ADT) and from observational studies in community-dwelling men. The collective evidence suggests that, in men, E2 is an important hormone for hypothalamic-pituitary-testicular axis regulation, reproductive function, growth hormone insulin-like growth factor-1 axis regulation, bone growth and maintenance of skeletal health, body composition and glucose metabolism and vasomotor stability. In other tissues, particularly brain, elucidation of the clinical relevance of E2 actions requires further research. From a clinical perspective, the current evidence supports the use of testosterone as the treatment of choice in male hypogonadism, rather than aromatase inhibitors (which raise testosterone and lower E2), selective androgen receptor modulators and selective estrogen receptor modulators (with insufficiently understood tissue-specific estrogenic effects). Finally, E2 treatment, either as add-back to conventional ADT or as sole mode of ADT could be a useful strategy for men with prostate cancer.
\end{abstract}

\section{Introduction}

Estrogens were demonstrated in the urine of men in the 1920s (1) and in the testis in 1952 (2). In 1937 Steinach and Kun demonstrated that administration of large doses of testosterone to men increased the estrogenic activity of their urine and inferred in vivo conversion of testosterone to estrogens (3). Subsequent advances included the identification, isolation, sequencing and regulatory characterization of the aromatase cytochrome P450 enzyme, product of the CYP19A1 gene, the enzyme responsible for aromatization of testosterone to $17 \beta$

\section{Invited Author's profile}

Mathis Grossmann, MD, PhD, FRACP, is a physician-scientist trained in both basic biology and in clinical endocrinology. He is a professor of medicine at the Department of Medicine (Austin Health), University of Melbourne and consultant endocrinologist and head of men's health at Austin Hospital, Melbourne, Australia. His research focuses on the regulation of musculoskeletal and cardiometabolic health by androgens and estrogens, both at the clinical and the molecular levels.

(C) 2019 European Society of Endocrinology Printed in Great Britain
Published by Bioscientifica Ltd. 
estradiol (E2) and androstenedione to estrone (E1), the major endogenous estrogens (4). Many other nonaromatized endogenous steroids, estrogen metabolites and environmental and pharmaceutical compounds with diverse structures have minor estrogenic activity $(5,6)$.

For this review the PubMed database was searched using the MeSH terms 'estradiol' and 'men', from inception to November 1, 2018. Reference lists from relevant retrieved articles were used to identify further relevant papers. Although pre-clinical models have been instrumental in elucidating relevant biological mechanisms, this review will predominantly discuss human studies. Table 1 provides a summary of conclusions drawn from these human studies.

\section{Physiology and metabolism of estrogens}

\section{Circulating E2 in men}

One quarter to one half of circulating E2 is estimated to originate from direct testicular secretion, with the rest resulting from peripheral aromatization of testosterone, particularly in adipose tissue, muscle, bone and brain $(7,8,9)$. Median serum E2 concentrations are around $150 \mathrm{pmol} / \mathrm{L}$ in healthy young men and $90 \mathrm{pmol} / \mathrm{L}$ in healthy older men, compared to $400 \mathrm{pmol} / \mathrm{L}$ in premenopausal women, while healthy male circulating testosterone concentrations are substantially higher, ranging from about 10 to $30 \mathrm{nmol} / \mathrm{L}$, although these concentrations vary across studies performed in different populations and using different assay methodologies $(10,11)$.

\section{Metabolism of estrogens}

The predominant metabolic pathway for $\mathrm{E} 2$, the most potent endogenous estrogen, is reversible oxidation to $\mathrm{E} 1$ by the widely distributed $17 \beta$ hydroxysteroid dehydrogenase (12). For infusions of labeled steroid, oxidation of $\mathrm{E} 2$ to $\mathrm{E} 1$ is more rapid than the reductive reaction (13). E2 and E1, the parent estrogens, undergo irreversible hydroxylation at the 2-, 4- or 16-carbon positions by cytochrome P450 enzymes, particularly CYP1A2 and CYP3A4, located in the liver and other tissues (14). The 4-hydroxy-estrogens are similar in potency to the parent estrogens, while the 2-hydroxy-estrogens are less potent and therefore, because they retain ER-binding affinity, may be relatively anti-estrogenic (15). The 2 - and 4-hydroxylated metabolites undergo methylation to less active forms (16). The $16 \alpha$ hydroxyestrogens, including estriol (E3), retain minor estrogenic activity (17).
In a parallel metabolic pathway, the parent estrogens, and their metabolites, are reversibly inactivated through conjugation with sulfate, glucuronide or glutathione, by widely distributed conjugation enzymes $(16,18)$. Estrogen conjugates can not only be excreted in urine or bile but also may circulate in blood and reach target tissues where deconjugation may occur to release active estrogens. Despite their abundance, estrogen metabolites are not commonly measured, although this is likely to change with increasing clinical availability of mass spectrometry (16).

\section{Estrogen receptors in men}

$\mathrm{ER} \alpha$ and ER $\beta$, encoded by the ESR 1 and ESR2 genes respectively, are members of the nuclear receptor superfamily. Multiple isoforms of each receptor type exist, created by differential splicing of exons (19). More recently, the transmembrane G-protein-coupled estrogen receptor 1 (GPER) was identified (20). ERs are expressed throughout the human male reproductive tract, and also in male brain, cardiovascular system, liver, bone, adipose tissue, pancreatic islets and skeletal muscle (21).

ER signaling occurs via a number of distinct pathways (22). The classic ligand-dependent pathway involves ligand-activated ER dimerization with direct DNA binding to estrogen response elements (EREs) in gene promoters leading to the regulation of transcription. $\mathrm{ER} \alpha$ and $\operatorname{ER} \beta$ bind to the same ERE. Other ligand-dependent pathways involve interaction of the ER with coregulators and additional transcription factors, allowing interaction with gene promoters that do not contain ERE. The ER can also be activated to modulate gene transcription in a ligand-independent fashion, by second messenger kinases involved in signal transduction by receptors of growth factors. There are also non-genomic pathways by which ER ligand binding induces rapid physiological effects (23).

\section{Intracrinology of estrogens}

Most clinical studies infer biological actions from serum E2 concentrations, based on the classical endocrine concept that gonadal-produced sex steroids circulate to target tissues to exert their effects. These studies do not take into account cellular uptake, either after dissociation from SHBG or albumin or perhaps as an SHBG-bound complex (24), nor local production and metabolism of sex steroids in target tissues themselves, with potential for autocrine and paracrine actions. As reviewed elsewhere (25), some extragonadal tissues possess the 
Table 1 Biological roles of estradiol in men.

\begin{tabular}{|c|c|}
\hline System & Process \\
\hline HPT axis & Negative feedback \\
\hline Reproduction & $\begin{array}{l}\text { Testicular descent and } \\
\text { spermatogenesis } \\
\text { Maintenance of libido and } \\
\text { erectile function } \\
\text { Prostate development, } \\
\text { hypertrophy, } \\
\text { carcinogenesis }\end{array}$ \\
\hline
\end{tabular}

GH-IGF-1 axis Pituitary GH secretion

Hepatic IGF-1 secretion

Bone Growth

Attainment and maintenance of bone mass

Body composition Muscle mass and strength Fat mass

Metabolism

$$
\begin{aligned}
& \text { Glucose metabolism } \\
& \text { Lipid metabolism } \\
& \text { Masculinization of brain } \\
& \text { anatomy and physiology }
\end{aligned}
$$

Cognition

Temperature regulation

\section{Comment}

- E2 produces negative feedback on GnRH pulse frequency, probably indirectly via KNDy neurons.

- E2 produces negative feedback on LH pulse amplitude by reducing pituitary gonadotrope sensitivity to $\mathrm{GnRH}$.

- ER signaling appears to play a role in testicular descent and spermatogenesis

- E2 appears to have a beneficial but non-essential role

- In vitro and animal models suggest a role for ER signaling in in utero prostate gland development.

- There is no definitive human data to define any role of E2 in BPH or carcinogenesis.

- In men with prostate cancer, clinical evidence is consistent with a net antineoplastic effect of estrogens if used at supraphysiological doses to reduce circulating $T$ to castrate concentrations.

- E2 appears to be the principal determinant of GH secretion with effects at both hypothalamic and pituitary level

- E2 inhibits hepatic IGF-1 response to GH

- E2 stimulates the pubertal growth spurt in boys likely via GH-IGF-1 axis stimulation

- E2 directly causes late pubertal growth plate closure

- E2, acting via ER $\alpha$ appears to be the predominant sex steroid for attainment and maintenance of normal bone mineral density and microstructure

- Minimal role if any

- E2 appears to prevent gain of fat mass. Data are mixed on whether this is a depot specific effect

- E2 appears to improve insulin sensitivity. Data are mixed on whether this is hepatic, peripheral or both

- E2 may not have any direct effect on lipid metabolism

- No role for E2 in brain development in men has been defined. Where reported, men with congenital $E R \alpha$ deficiency and aromatase deficiency have had cisgender identity

- No role for E2 in cognition has been proven and small trials of E2 add-back in men with castrate levels of T have not demonstrated any cognitive benefit

- E2 is the predominant sex steroid responsible for prevention of hot flushes
Clinical reference

$26,27,28,29,30,31$

$35,36,38$

$47,50,53,54$

64,65

68,69

$32,82,89,96,97$,

$102,103,104,105$

54

54,121

$121,129,133$

68

152,153

$53,104,157$

$\mathrm{BPH}$, benign prostate hypertrophy; E2, estradiol; ER, estrogen receptor; GH, growth hormone; HPT, hypothalamic-pituitary-testicular; IGF-1, insulin-like growth factor-1; KNDy, kisspeptin, neurokinin B and dynorphin; T, testosterone.

capacity for de novo sex steroid synthesis and/or for metabolism of circulating precursors, such as adrenal produced dehydroepiandrosterone sulfate, and express steroidogenic enzymes not reported to be active in gonadal tissues. The net biologic effects of such locally acting estrogenic compounds in individual target tissues are not known but, in combination with the use of inaccurate immunoassays, may contribute to the relatively modest associations of circulating E2 concentrations with biologic phenotypes reported in many clinical studies.

\section{Hypothalamic-pituitary-testicular axis regulation}

Human gonadotropin-releasing hormone (GnRH) neurons express $E R \beta$ but not $E R \alpha(26)$. It is likely that E2 acts on ER $\alpha$ in kisspeptin, neurokinin B, and dynorphinexpressing (so-called KNDy) neurons in the infundibular nucleus of the hypothalamus to regulate GnRH neurons indirectly (27). E2 also has direct effects on pituitary gonadotropin production $(28,29)$. 
In parallel experiments in healthy and GnRH-deficient men (with idiopathic hypogonadotropic hypogonadism; $\mathrm{IHH}$ ) receiving fixed GnRH treatment (generating a de facto hypothalamic clamp), the effect of an aromatase inhibitor (AI) on luteinizing hormone (LH) secretion was examined (30). By comparing LH responses in healthy men to LH responses in those undergoing the hypothalamic clamp, pituitary-dependent and hypothalamic-dependent effects of E2 withdrawal could be distinguished. In both groups, AI treatment suppressed serum E2 and elevated serum testosterone into the supraphysiological range. Despite the testosterone rise, LH increased in both groups, suggesting that aromatization of testosterone to E2 is required for negative feedback on LH secretion. For men undergoing the hypothalamic clamp, the site of this E2 effect must have been pituitary, and the authors inferred that, in normal physiology, E2 reduces pituitary sensitivity to GnRH, thereby reducing LH pulse amplitude. LH increments in healthy men were approximately twice those recorded in IHH men undergoing the hypothalamic clamp. This differential suggested an additional hypothalamic site of E2 action, likely to reduce GnRH pulse frequency. A subsequent study subjecting healthy and IHH men to experimental castration and simultaneous inhibition of aromatase by high-dose ketoconazole, and testosterone, E2 or placebo add-back concluded that, while E2 has dual feedback, its predominant negative effect occurs at the hypothalamus (31).

Rochira et al. examined gonadotropin secretion pre and post physiological E2 add-back in two men with congenital aromatase deficiency (29). Such men have normal to high serum testosterone. In these men, E2 add-back reduced LH pulse frequency, suggesting a role for circulating E2 in reducing hypothalamic GnRH action. When these men were given GnRH to stimulate gonadotropin secretion, E2 add-back reduced LH and follicle-stimulating hormone (FSH) secretory peaks and area under the curve, suggesting that circulating E2 also directly acts on the pituitary to reduce sensitivity to GnRH.

Direct androgen receptor (AR)-mediated negative hypothalamic-pituitary feedback also may occur in men. In a 2-year randomized controlled trial (RCT) of pharmacological doses of the non-aromatizable androgen dihydrotestosterone (DHT) designed to assess androgen effects on prostate growth in healthy older men, DHT suppressed testosterone, E2, LH and FSH to castrate concentrations (32). However, supraphysiological doses of pure androgen agonists, while providing evidence of the potential for pharmacological AR-mediated effects, do not prove that these effects are important in physiology. Experimental parallel design studies referred to above (31) using medical castration with ketoconazole and testosterone add-back have also concluded that testosterone exerts a direct negative hypothalamic feedback not requiring its aromatization to E2.

Additional indirect evidence comes from 46,XY women with complete androgen insensitivity syndrome (CAIS) due to inactivating AR mutations. These women have, despite circulating E2 sufficient to cause a female external phenotype, high concentrations of testosterone and LH. This suggests that E2 is not sufficient to maintain a normal LH concentration, but that AR-mediated effects are also required to reduce LH production (33). Whether these inferred effects are organizational during in utero hypothalamic-pituitary programming or activational AR-dependent effects in adulthood is not resolved by these case observations.

Overall, human studies suggest that E2-mediated negative feedback on gonadotropin activation involves both hypothalamic and pituitary actions. Moreover, while E2 is important for this negative feedback, it is likely that AR-mediated effects also play a role.

\section{Reproduction}

\section{Spermatogenesis}

A comprehensive discussion of the role of E2 in testicular function and spermatogenesis is beyond the scope of this manuscript and recent reviews exist (21). Briefly, ER $\alpha$ and ER $\beta$ are expressed throughout the human male reproductive tract, including in germ cells, although there are conflicting data in certain cell types. Aromatase is found in human immature germ cells, spermatozoa, efferent ductules of the testis and epididymis (21). While studies in mice have demonstrated important roles for estrogen signaling in male fertility, studies in men have been less dramatic and less conclusive.

Male ER $\alpha$-knockout mice are infertile due to disruption of fluid reabsorption in the efferent ductules of the epididymis (34). Testicular function has been reported in two men with homozygous missense mutations in ESR1 causing non-functional ER $\alpha$. The first man, at age 28 years, had descended testes of normal volume and normal sperm count with a minor reduction in sperm viability (35). The second man, at age 18 years, had a cryptorchid right testis, hypoplastic left testis and primary hypogonadism, but no semen analysis was reported (36). 
Aromatase-knockout mice exhibit progressively impaired spermatogenesis with aging (37), and abnormalities have been reported in men with congenital aromatase deficiency. In most cases, testicular size was normal $(38,39,40,41,42$, $43,44,45)$, although a few men had low testicular volume $(46,47,48,49)$, and cryptorchidism has been commonly reported $(43,45,47,48)$. Where reported, sperm counts were normal $(42,44)$ or reduced $(39,46)$, commonly with altered sperm motility $(44,46)$. A few men with aromatase deficiency have undergone testicular biopsy, showing varying degrees of impaired spermatogenesis including germ cell arrest $(46,48,49)$. These observations suggest a role for $\mathrm{E} 2$ in testicular descent and spermatogenesis. The fact that some men appear to have normal testicular function despite congenital lack of E2 has been postulated to be related to dietary phytoestrogen intake (37), although there is no direct evidence for this in humans. An alternative explanation is that men with aromatase deficiency would be expected to retain ligand-independent ER $\alpha$ signaling in the reproductive tract (50).

\section{Libido and erectile function}

The evidence from men with congenital non-functional $\mathrm{ER} \alpha$ or aromatase deficiency suggests that E2 is not essential for male libido and erectile function $(39,46)$, but various lines of evidence support some physiological role. In non-blinded studies, two men with aromatase deficiency had increments in libido and sexual activity during E2 treatment, either alone (51) or with testosterone (47). Non-definitive evidence from men with prostate cancer suggests that androgen deprivation therapy (ADT) using estrogens may better maintain sexual function than surgical castration (52) and GnRH analogs (53).

In a physiological experiment, Finkelstein et al. gave a GnRH analog with or without AI to 400 healthy young men for 16 weeks (54). Participants were further randomized to add-back with one of five transdermal testosterone gel doses that produced serum testosterone concentrations ranging from castrate to mildly supraphysiologic, either with E2 clamped to very low concentrations (AI cohort) or with the expected corresponding E2 increments for each testosterone dose increment (non-AI cohort). This design allowed for discrimination of testosterone from E2-dependent effects. Testosterone-related effects were assessed directly by comparing changes between groups of men in whom E2 was clamped. E2-related effects were inferred indirectly, by comparing mean change for each outcome in the AI cohort with the outcome in the non-AI cohort, and also by linear regression modeling of the cohort-testosterone dose interaction. In this analysis, E2 clearly exerted a positive effect on sexual interest and erectile function, independent of testosterone. Assignment to the AI cohort was not randomized and there was no placebo, so the possibility of systematic differences between cohorts that were not due to differences in serum E2 is not completely excluded. Moreover, although not reported, it cannot be excluded that potential adverse effects of AI (e.g. hot flushes and associated sleep disturbance), in addition to their E2-lowering actions, might have contributed to reductions in libido.

\section{Prostate}

Estrogens are synthesized by aromatase in the prostate stroma (55) and have autocrine and paracrine actions. $\mathrm{ER} \alpha$ appears to be primarily located in prostate stromal cells while ER $\beta$ is found primarily in the epithelium (56). GPER has been demonstrated in stromal cells and epithelial progenitor cells (57). Estrogens appear to have a role during normal prostate development in utero, a time of high systemic estrogen exposure $(56,57)$. However, unphysiologically timed or dosed estrogen exposure during prostate gland development influences later prostate cancer risk in animal models (58).

Aromatization to E2 is hypothesized to be important in testosterone-stimulated prostate growth, although there are clearly AR-mediated effects illustrated by the fact that $5 \alpha$-reductase inhibitors are effective in treating symptoms of benign prostatic hypertrophy (BPH) (63). A recent small trial $(n=31)$ was conducted to differentiate aromatization from non-aromatization-dependent effects of testosterone on $\mathrm{BPH}$ in men receiving testosterone replacement for age-associated mildly low testosterone (59). Men were randomized to placebo, transdermal testosterone or transdermal testosterone plus AI. The primary outcome was change in prostate volume after 12 months. Men receiving testosterone alone had a small significant increase in prostate volume compared with placebotreated and testosterone/AI-treated men, leading the authors to infer that the tropic effects of testosterone on the prostate are aromatization dependent. Adding support to this hypothesis, in a 2-year trial of DHT treatment of older men; gonadotropins, E2 and T were suppressed, with maintenance of AR-signaling (32). In this trial, there was no difference in prostate growth between DHT and placebo arms. However, these results are difficult to interpret because the study was designed to test the hypothesis that DHT would actually inhibit prostate growth via ER $\beta$-mediated effects of its metabolite, $3 \beta$ Adiol. 
Aberrant aromatase expression has been demonstrated in human prostate adenocarcinoma epithelial cells suggesting the potential for autocrine signaling via $E R \alpha$ (55). ER $\alpha$ activation has proliferative effects in the prostate, but ER $\beta$ - and GPER-mediated effects appear to be antiproliferative and anticarcinogenic $(60,61)$. As a result, the net effect of estrogenic signaling in normal prostate or prostate cancer cells has been difficult to predict, and biologic effects may differ between healthy and diseased prostate. Evidence from rat models suggests important roles for genotoxicity of hydroxylated estrogen metabolites in inducing prostate carcinogenesis (62).

The clinical evidence is largely consistent with a net antineoplastic effect of estrogen-based treatment if used at supraphysiologic doses to reduce circulating testosterone to castrate concentrations in men with prostate cancer. Conversely, in men with castrate resistant prostate cancer, trials of estrogen signaling ablation through the use of AI in addition to surgical or medical castration did not show any clinical benefit (63). While benefits in early studies using oral estrogens were negated by cardiovascular toxicity due to the prothrombotic hepatic first-pass effect (64), more recent smaller studies using high-dose transdermal E2 as a sole mode of ADT have not reported increased cardiovascular risks (65). Overall, these clinical trials suggest that potential prostate cancer-promoting effects of estrogenic signaling appear outweighed if procarcinogenic testosterone signaling is abolished.

In summary, the collective evidence from rare case studies (including ER and aromatase-deficient men) and experimental studies in healthy younger and older men is consistent with the fact that ER signaling plays a role in various aspects of male reproductive health, including testicular descent, spermatogenesis and sexual function. ER signaling also has complex effects on the prostate gland, but the consequences for prostate health and disease are poorly understood.

\section{Growth hormone insulin-like growth factor-1 axis}

Men with congenital aromatase deficiency have impaired stimulated growth hormone $(\mathrm{GH})$ secretion and low insulin-like growth factor-1 (IGF-1) (66). Exogenous E2 in these men was not able to normalize GH secretion (66), possibly because of abnormal development of the GH-IGF-1 axis in the setting of congenital E2 deficiency or because restoration of normal circulating E2 concentration is insufficient if local E2 production remains impaired
(67). Additional lines of evidence from preclinical models, women, and indirect evidence from men, suggest that E2 is important in regulation of $\mathrm{GH}$ secretion by both direct and indirect mechanisms $(67,68)$.

Using a T/E2 clamp in healthy older men (GnRH analog plus intramuscular (IM) testosterone add-back plus AI plus transdermal E2 or placebo controls), Roelfsema et al. isolated the effect of E2 on GH secretion (68). The primary endpoint, overnight GH secretion on day 22 of the intervention, was 50\% higher in the $\mathrm{E} 2$ arm than the transdermal placebo arm. Mean E2 concentration $301 \pm 66 \mathrm{pmol} / \mathrm{L}$ was triple the basal E2 concentration $(91 \pm 5 \mathrm{pmol} / \mathrm{L})$. Pulsatile GH secretion was strongly positively correlated with E2 concentration. The authors concluded that E2 is the principal determinant of GH secretion in men. In pituitary stimulation tests, there was no difference in GH secretion between groups, raising the possibility that the E2 effect may be at the level of the hypothalamus. However, Er $\alpha$ and ER $\beta$ are expressed in pituitary somatotrophs, and in vitro data show that, although the GH promoter lacks ERE, E2 acts via ER $\alpha$ and ER $\beta$ to stimulate pituitary-specific positive transcription factor 1 , a potent $\mathrm{GH}$ transcription factor, which in turn upregulates somatotroph GH synthesis and release (69).

E2-stimulated GH in Roelfsema's study did not produce an increase in IGF-1 concentration (68). Despite stimulating GH release, E2 inhibits hepatic IGF-1 response to GH so that the net effect of E2 on IGF-1 depends on relative exposure of hypothalamus/pituitary and liver $(70,71)$. E2 inhibits the hepatic IGF-1 response to GH by stimulating suppressor of cytokine signaling (SOCS)-2, which inhibits the Janus kinase 2 (JAK)2 phosphorylation downstream of the $\mathrm{GH}$ receptor, and thus, the transcription signal for IGF-1 (70).

In summary, E2 rather than testosterone appears the main sex steroid regulator of the GH-IGF-1 axis in men.

\section{Bone}

Osteoblasts, osteocytes, osteoclasts and marrow stromal cells contain ER and AR $(72,73)$. The weight of evidence points to E2, acting via ER $\alpha$, as the predominant sex steroid in the development and maintenance of the male skeleton (74). Androgens have a smaller but important role, particularly in promoting periosteal apposition to increase bone size in men.

E2 has multiple direct and indirect actions, the net effect of which is to maintain remodeling balance by reducing bone resorption and increasing bone formation. 
Based largely on preclinical evidence, and some studies in women, the predominant actions of E2 are to inhibit differentiation and promote apoptosis of osteoclasts and promote differentiation and inhibit apoptosis of osteoblasts. E2 alters cytokine production from bone and immune cells in ways that limit bone resorption, in particular by reducing T-cell tumor necrosis factor- $\alpha$ production, and the secretion ratio of nuclear factor kappa B ligand to osteoprotegerin by osteoblast lineage cells (73). In preclinical studies, ligand-independent effects of ER $\alpha$ and ER $\beta$ in osteoblast lineage cells are important for mechanotransduction, the homeostatic mechanism by which bone strength of load-bearing bones is regulated according to the power of the muscles acting upon them (75).

\section{E2, linear bone growth, cessation of growth and achievement of peak bone mass}

E2 has concentration-dependent effects on skeletal growth. Pre-puberty, serum and tissue E2 is extremely low, and skeletal growth, more appendicular than axial, is mediated by the GH-IGF-1 axis (76). Skeletal sexual dimorphism does not arise until puberty (77). Men are taller than women, predominantly because of a longer period of prepubertal growth, leading to longer leg length (78).

In early puberty, in boys and girls, increased serum and tissue E2 concentrations stimulate the pubertal growth spurt, with acceleration of truncal and deceleration of appendicular growth $(79,80,81)$. The E2 effect on growth in boys was demonstrated by the growth charts pre and post initiation of E2 treatment in a young man with congenital aromatase deficiency. At age 17 years, before treatment, bone age was 12 years, Tanner stage V, testosterone concentrations were supranormal and E2 was undetectable. In this man, growth continued after initiation of E2 treatment, with an increase in relative height from the 50th centile at age 17 to the 90th centile at age 20 (40). In contrast, in an older (age $=27$ years) man with congenital aromatase deficiency, E2 treatment initiation resulted in rapid epiphyseal closure and termination of linear growth within 12 months (82). These observations do not resolve the mechanism of the early pubertal effect of E2 on increasing linear growth in men. Pre-clinical studies suggest that this is likely to be an indirect action via E2-mediated stimulation of the GH-IGF-1 axis. This has been recently reviewed elsewhere (83).

In late human puberty, higher E2 availability at the growth plate in both sexes causes growth plate closure and cessation of growth (79). This is a direct effect of
E2 in inhibiting proliferation and promoting apoptosis of chondrocytes (84). Higher E2 in girls stimulates an earlier cessation of growth so that boys have a longer period of intra-pubertal growth and greater adulthood truncal length (78). Men with prepubertal hypogonadism do not experience a pubertal growth spurt, but develop tall stature with eunuchoid proportions, characterized by greater leg and lesser truncal length, because of failure of E2-mediated growth plate closure. However, the tall stature in Klinefelter syndrome has a pre-pubertal onset and is likely to be partly due to an increased dose of growthpromoting genes on the additional X chromosome (such as sex chromosome-related short stature homeoboxcontaining gene, SHOX, which influences chondrocyte differentiation) (85).

ESR1 (86) and CYP19 (87) polymorphisms are associated with adult height but large genome wide association studies (GWAS) on adult height have identified hundreds of other loci across the genome. In a recent study of over 250,000 individuals of European ancestry, 697 variants, clustered in 423 loci explained $20 \%$ of the heritability in height (88). The genes in these loci are particularly highly expressed in tissues related to chondrocytes and osteoblasts and included many newly associated genes involved in skeletal and cartilage development.

The two reported men with non-functional ER $\alpha$ had delayed bone maturation. In the first case, in which testicular size and serum testosterone were normal (35, 89), there was absence of the pubertal growth spurt and delayed epiphyseal closure resulting in continued linear growth into adulthood. This was accompanied by reduced bone mass, even adjusted for low bone age. Cortical thickness and trabecular volume were reduced. The second man had an undescended right and hypoplastic left testis, low serum testosterone and delayed bone age, but bone mineral density (BMD) data were not reported (36). Interestingly the best characterized man with nonfunctional ER $\alpha$ (89) had a low bone remodeling state, which is in contrast to the high bone remodeling seen in men with congenital aromatase deficiency (40) and hypogonadism $(90,91)$. This may indicate a non-liganddependent role for ER $\alpha$ in promoting bone remodeling or roles for ER $\beta$ or GPER in suppressing remodeling $(36,74)$. These non-ERo-mediated effects of $\mathrm{E} 2$ are potentially over-activated in men with non-functional ERo-induced E2 resistance, which results in high serum E2 and could be invoked to explain other features of the skeletal phenotype. However, the phenotype is similar in men with congenital aromatase deficiency: lack of pubertal growth 
spurt; continued linear growth after sexual maturation, leading to tall stature; genu valgum and low bone mass. This phenotype is remediable with E2 therapy $(40,82)$. Together, these observations suggest that $\mathrm{E} 2$ signaling via $\mathrm{ER} \alpha$ is critical in normal male bone development.

Peak bone mass at the completion of growth is an important determinant of lifetime fracture risk (77). It is a function of bone mineral content and bone size. During puberty, men have greater periosteal bone expansion than females, resulting in greater cortical width and peak bone mass in adulthood. Women have less periosteal bone formation and predominantly increase cortical width by endocortical apposition (77). Evidence from rodents suggests that sex differences in radial bone growth depend on an intact GH-IGF-1 axis (92), but the neonatal testosterone surge imprints the adult male $\mathrm{GH}$ secretory pattern (93). In rodents, there appears to be direct AR-mediated effects in late puberty (92). This also appears to be the case in humans because women with 46,XY CAIS have deficits in spine BMD despite never being estrogen deplete (94). Additionally, the Gothenburg Osteoporosis and Obesity Determinants (GOOD) study of a large homogenous cohort of 18- to 200year-old men reported that periosteal circumference at the time of peak bone mass was positively associated with cross-sectional serum-free testosterone and negatively associated with free E2, noting that sex steroids were measured by immunoassay rather than more accurate methods, and that free hormone fractions were calculated rather than measured directly (95). However, at least some of the testosterone effect on periosteal expansion in men is aromatase dependent because $\mathrm{E} 2$ treatment of a 17 yearold man (bone age 12 years) with congenital aromatase deficiency produced a dramatic increase in bone size and cortical thickness (40).

SNPs in CYP19 are associated with serum E1 and E2 concentrations in European and Chinese adult men in GWAS $(96,97)$. Mendelian randomization analysis using summary results from the European GWAS (97) and BMD data from various cohorts contributing to the Genetic Factors in Osteoporosis Consortium reported a positive relationship between serum E2 and BMD at the lumbar spine (LS) and femoral neck to the extent that a $3.7 \mathrm{pmol} / \mathrm{L}$ genetically increased serum E2 was associated with a 0.048 standard deviation increase in LS BMD measured in adulthood (97). The mean age of participants in the various cohorts ranged from 18 to 76 years. Within general caveats of Mendelian analyses, this provides strong evidence of a causal link between E2 and BMD. In contrast, testosterone concentrations were not associated with these SNPs. Whether genetically determined E2 is most important in the achievement of peak bone mass or in the attenuation of bone loss in older men is not resolved by Mendelian randomization.

In the GOOD study, peak areal BMD in a large homogenous cohort of 18- to 20-year-old men was shown to be associated with aromatase gene polymorphisms, with the association mediated by differences in cortical bone size (a function of cross-sectional area and thickness) (98). The polymorphisms associated with greater cortical bone size were associated with higher cross-sectional testosterone, suggesting lower aromatase activity, although serum E2, measured by immunoassay, was no different between genotypes, and statistically, testosterone concentrations did not account for the effect of polymorphisms on bone mass. Thus, the mechanism of this association remains unclear. The authors speculated that differences in earlier, pubertal, testosterone concentrations, not measured in this cross-sectional study, may be responsible for differences in periosteal apposition leading to the differences in cortical bone thickness.

\section{E2 and bone loss in older men and in models of hypogonadism}

Severe hypogonadism in older men induces accelerated bone remodeling and deterioration in bone density and microarchitecture (91). Observational and experimental evidence suggests that these effects are mostly E2 dependent.

Among older men, epidemiological studies have generally found closer correlations between serum E2, particularly non-SHBG-bound E2, and BMD, microstructure and fractures than with serum testosterone and these parameters $(99,100,101)$. AIs, which lower E2 and increase testosterone (102), and treatment with DHT, a non-aromatizable androgen which lowers E2 concentrations (32), both reduce BMD in men.

Short-term experiments of GnRH analog-induced hypogonadism in healthy men combined with AI treatment and add-back of testosterone or $\mathrm{E} 2$ have assessed the relative importance of each hormone in maintenance of BMD and suppression of abnormal bone remodeling. In one such study, Falahati-Nini et al. used a GnRH analog plus AI in 59 healthy older men with transdermal add-back of physiological doses of testosterone and E2. Following baseline assessment of bone remodeling markers at week 3, either T, E2, both or neither were withdrawn, and repeat measurements were made at week 6 (90). Sex steroid withdrawal leads to an increase 
in urinary deoxypyridinoline and $\mathrm{N}$-telopeptide of type 1 collagen, indicating resorption of mineralized matrix. Significant increases were prevented by E2 add-back, even without testosterone, and in an analysis of variance model, testosterone had no independent effect. In this study, the osteoblast lineage marker, pro collagen type 1 amino-terminal propeptide (P1NP), fell with testosterone and E2 withdrawal, and this effect was prevented by E2 but not testosterone.

In Finkelstein's study (discussed above) (54), 16 weeks of induced hypogonadism in healthy younger men caused elevations in serum beta carboxyl-terminal type 1 collagen telopeptide (CTX) and declines in BMD by quantitative computed tomography which were greater in men who received AI at each active testosterone replacement dose (103). In another 4-week RCT enrolling men rendered chronically hypogonadal with GnRH analogs for prostate cancer, transdermal E2 add-back reduced serum CTX and increased P1NP, consistent with short-term anti-resorptive and pro-osteoblastic effects (104). These studies suggest that the high remodeling rate and bone loss that occurs in male hypogonadism is primarily due to E2 deficiency. However, short-term studies revealing differential changes in biomarkers of resorption and formation cannot be used to infer longterm effects of sex steroid withdrawal or treatment, because of steady state coupling of these processes.

Longer-term interventional data are available from a bone sub-study of an ongoing trial of ADT with transdermal E2 (high E2, castrate testosterone) versus GnRH analogs (castrate testosterone and E2) in men with advanced prostate cancer (105). This sub-study enrolled 74 men who underwent dual energy x-ray absorptiometry (DXA) scans at baseline and annually for 2 years. The primary endpoint, 1-year change in spine BMD, was analyzable for 60 participants, with an estimated difference between arms was $6.7 \%$ (95\% CI 3.7-9.7) in favor of E2.

\section{Serum E2 and fractures in men}

Many observational studies have observed an association between serum E2, particularly free E2, and fracture risk in older men $(100,106,107)$. In general, attributable risks are modest, and the association is not a universal finding $(108,109,110)$. A high-quality longitudinal study measuring sex steroids by mass spectrometry in 1700 men (mean age $76.9 \pm 5.5$ years) showed no association of $\mathrm{E} 2$ with change in BMD or incident fractures over 6 years, although free E2 was not reported and only 10\% of participants had an incident fracture (110). A large
Mendelian randomization study of E2-associated and testosterone-associated SNPs on fracture risk was recently reported (111). This study used data from 175,583 men of European origin, captured as part of the UK Biobank. The men enrolled in the study were aged $56.9 \pm 8.1$ years and self-reported 17,650 fractures. A genetically reduced serum E2 by 1 SD (35.2 pmol/L) was robustly associated with an increased risk of any self-reported fracture (OR 1.35; 95\% CI 1.18-1.55). There was no causal effect of genetic alterations in serum testosterone on fracture risk.

Although further research is required in populations in whom hypogonadism has been rigorously excluded, reported mass spectrometry reference ranges for serum E2 range from 38 to $196 \mathrm{pmol} / \mathrm{L}$ in men aged $<65$ years, 23 to $154 \mathrm{pmol} / \mathrm{L}$ (65-75 years), 22 to $166 \mathrm{pmol} / \mathrm{L}$ (75-85 years) and 22 to 174 (>85 years) (112). Thresholds of $37-92 \mathrm{pmol} / \mathrm{L}$ have been suggested to be necessary for skeletal health in men, based on observational and experimental data $(103,113)$.

In summary, the available data suggest that, while testosterone has direct effects on bone remodeling and bone microstructure, and indirect effects though anabolic effects on skeletal muscle, E2 appears to be the sex steroid predominantly important for skeletal health in men.

\section{Body composition and glucose and lipid metabolism}

\section{Body composition: E2, muscle and fat}

In men, aromatase activity is reported in skeletal muscle (114) and adipose tissue (9). Aromatase is strongly expressed in the stroma of human adipose tissue, although nearly all of these data are from women (115). ERs are also expressed in human adipose tissue (116) and there is low level expression of ER $\alpha$ in human skeletal muscle (117).

E2 does not appear to be important for muscle size or strength. In Finkelstein's study (discussed above) (54), healthy younger men rendered hypogonadal with $\mathrm{GnRH}$ analogs lost muscle mass, size and strength over 16 weeks. These losses were testosterone dependent, decreasing below a threshold of approximately $6.9 \mathrm{mmol} / \mathrm{L}$, with no independent effect of E2.

In the same study, experimental profound hypogonadism caused gains in subcutaneous and intraabdominal fat (54). These were predominantly due to E2 deficiency as they occurred in AI-treated men, irrespective of testosterone replacement dose. In the AI-treated men, percentage body fat and subcutaneous fat area gains were attenuated in men receiving supraphysiological 
testosterone replacement, suggestive of pharmacological AR-mediated effects. This is in agreement with RCTs reporting reductions of fat mass using pharmacological doses of non-aromatizable androgens $(32,118)$. Such AR-mediated effects on fat mass might be secondary to increased muscle mass, and lipolytic myokine production (119) or diversion of pluripotent stem cells from adipogenesis and toward myogenesis (120).

In an RCT, Juang et al. treated young obese men without diabetes with a GnRH antagonist plus supraphysiological transdermal testosterone add-back with either dutasteride to inhibit reduction to DHT (dutasteride group), AI to inhibit aromatization to E2 (AI group), or placebo (testosterone-only group) (121). A separate group received placebos for all four treatments (placebo group). Body composition by DXA was assessed at baseline and 14 weeks. Compared with the placebo and AI groups, serum E2 increased, proportion fat-free mass increased and proportion fat mass decreased in the dutasteride and testosterone-only groups suggesting an E2-dependent effect. As others have pointed out, systemic E2 withdrawal in the context of testosterone add-back in Finkelstein's and Juang's studies would be expected to lower GH and IGF-1 which might have contributed to the body composition effects attributed to E2 withdrawal (122).

Other human data support a role for E2 in limiting fat gain. Men with congenital aromatase deficiency are generally overweight or obese with excess abdominal adiposity $(38,39,40,42,44,45,46,48,49)$. In one 9-month RCT randomizing abdominally obese men older than 40 years $(n=31)$ to transdermal DHT, transdermal testosterone or placebo, DHT treatment increased visceral adipose tissue (VAT) with no change in subcutaneous adipose tissue (SAT) or lean mass compared to testosterone-treated men (123). In another 24-month RCT of DHT treatment to inhibit prostate growth in 114 healthy men 50 years of age or older, DHT increased lean mass by $1.0-1.5 \mathrm{~kg}$ together with a small increase in grip strength as expected (32). However, there was a decrease in fat mass by $1.0-1.5 \mathrm{~kg}$ in the DHT group with a small increase in the placebo group, although the betweengroup difference was non-significant. VAT and SAT were not distinguished in this study. Because DHT is nonaromatizable, and profoundly suppresses serum E2 and testosterone, a specific effect of $\mathrm{E} 2$ in limiting fat mass, predominantly VAT, mass could be inferred from these studies. However, as discussed above, another theoretical

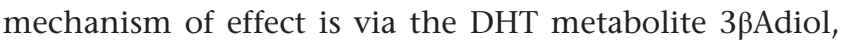
an agonist at $\operatorname{Er} \beta$. $\operatorname{Er} \beta$ is expressed in human adipose tissue
(116) and in pre-clinical studies appears to be a negative regulator of peroxisome proliferator-activated receptorgamma-induced adipogenesis (124). The hypothesis of depot-specific effects of E2 are supported by differential expression of ER $\beta 1$ isoforms, which are reduced in VAT compared to SAT (116).

\section{Effects of obesity on E2}

Observational studies have consistently found a negative linear correlation between serum testosterone and body mass index in men (125). Insulin resistance lowers SHBG and therefore total testosterone, but as obesity increases, free testosterone also falls, and this is associated with low or inappropriately normal LH. One hypothesized mechanism is that in obesity, excess adipose tissue aromatase activity elevates E2 concentrations, which increases negative feedback on LH production. In the 1970s higher E1 and E2 serum concentrations and urinary production rates were reported in obese men compared with lean controls (126). However, there are little subsequent data to support the excess aromatization hypothesis. For example, a study by Dhindsa et al. employed mass spectrometry and equilibrium dialysis to accurately measure total and free E2 in obese men with type 2 diabetes with either subnormal or normal serum free $T$ (127). Men with subnormal free testosterone had lower E2 concentrations than those with normal serum free testosterone. In Dhindsa's study, and also in the European Male Aging Study in which men mostly did not have diabetes (128), testosterone and E2 concentrations were positively correlated.

\section{Glucose metabolism}

Subnormal serum testosterone is prevalent in men with type 2 diabetes. Contrary to the hypothesis that this low testosterone is due to negative feedback from elevated serum E2 produced by excessive adipose tissue aromatase, Dhindsa et al. showed that E2 in men with type 2 diabetes is low and remains directly correlated with serum testosterone (127).

E2 may have beneficial effects on glucose metabolism. Men with congenital aromatase deficiency are reported to have insulin resistance, which improves with $\mathrm{E} 2$ treatment (129). In male mice, E2 appears to have direct beneficial effects, acting via hepatic ER $\alpha$ in the liver to improve insulin sensitivity (130). Rodent studies also suggest beneficial effects of $\mathrm{E} 2$ signaling on insulin sensitivity in other tissues, such as the brain, skeletal muscle, adipose tissue and pancreatic islet cells (131). E2 may also 
have intracrine actions; in male mice, overexpression of aromatase targeted to white adipose tissue (WAT) increased WAT E2 concentrations and expression of Glut4 and Irs1, associated with improved insulin sensitivity, without measurable changes in circulating sex steroid concentrations (132). In a hyperinsulinemic-euglycemic clamp study in healthy young men randomized to AI or placebo, AI treatment reduced insulin-stimulated peripheral glucose disposal but had no effect on insulinmediated suppression of endogenous glucose production, letting the authors infer a skeletal muscle effect (133). However, as in other studies of AI alone (without GnRH analog to suppress gonadotropins), treatment results in an increase in testosterone which confounds interpretation.

In the study by Juang et al. (described above) (121), insulin sensitivity was measured by euglycemichyperinsulinemic glucose clamp at baseline and 14 weeks. There were significant between-group differences in change in insulin sensitivity, with the dutasteride group (GnRH analog plus testosterone plus dutasteride) showing increases in insulin sensitivity which were not seen in the testosterone-only (GnRH analog plus testosterone) or AI group ( $\mathrm{GnRH}$ analog plus testosterone plus AI). The authors infer an effect of E2 in improving insulin sensitivity which is inhibited by DHT. Both global and peripheral insulin sensitivity improved.

\section{Lipid metabolism}

In men with prostate cancer, ADT with GnRH analogs, which reduces both testosterone and E2 to castrate concentrations, appears to alter lipids in a pattern distinct from the dyslipidemia of metabolic syndrome. Studies have been non-randomized by necessity and have made heterogeneous observations about changes in lipid parameters. Additionally, many of these studies were uncontrolled, and likely confounded by ADT-induced changes in body composition, insulin resistance and physical activity. Most $(134,135,136)$ but not all (137) controlled studies report that ADT is associated with a modest increase in total cholesterol (TC) (7-10\%) and triglycerides (TG) (25\%). These studies observed either an increase $(134,135)$ (up to $7 \%$ ) or no change (136) in lowdensity lipoprotein cholesterol (LDL-C) and an increase (134) (up to $20 \%$ ) or no change $(135,136)$ in high-density lipoprotein cholesterol (HDL-C). In a 6-month placebocontrolled trial of GnRH analog therapy in 50 men with benign prostatic hyperplasia, TC, HDL-C and TG increased compared to placebo, with no change in LDL-C (138). Lipids returned to baseline after the intervention.
In another RCT enrolling 15 healthy men, induction of hypogonadism using a GnRH analog increased TC and HDL-C compared to placebo with no change in LDL-C or TG (139). Testosterone replacement prevented these changes, but the study was not designed to differentiate aromatization-dependent effects.

Roelfsema et al. performed a short-term clamp study to isolate the effect of physiological E2 concentration on lipids and inflammatory markers in healthy older men (140). This design avoided confounding effects of changes in body composition and physical activity. Over 3 weeks, 74 men were rendered acutely hypogonadal by a GnRH antagonist followed by randomization to IM testosterone add-back or placebo, AI or placebo, and transdermal E2 patch or no patch. Four groups were analyzed: IM placebo (T-E2-); IM T plus oral placebo (T+E2+); IM T plus oral AI (T+E2-) and IM T plus AI plus E2 patch (T+E2++). Mean serum testosterone concentrations were $14.9-17.3 \mathrm{nmol} / \mathrm{L}$ at baseline. The intervention produced testosterone concentrations of $5.7 \mathrm{nmol} / \mathrm{L}$ in the testosterone-E2 group, different from the 25.9 to $29.3 \mathrm{nmol} / \mathrm{L}$ in the three groups receiving testosterone add-back. Mean serum E2 concentrations were $77-99 \mathrm{pmol} / \mathrm{L}$ at baseline, then $4 \mathrm{pmol} / \mathrm{L}$ in the testosterone+E2- group, $35 \mathrm{pmol} / \mathrm{L}$ in testosterone-E2- group, $115 \mathrm{pmol} / \mathrm{L}$ in the $\mathrm{T}+\mathrm{E} 2+$ group and $301 \mathrm{pmol} / \mathrm{L}$ in the $\mathrm{T}+/ \mathrm{E} 2++$ group. Despite an 80-fold range of serum E2 concentrations encompassing the physiological range, linear regression analysis showed that TC, LDL-C, HDL-C, TG, lipoprotein (a) and apolipoprotein B were unrelated to serum E2 or testosterone concentrations. While larger studies are needed to confirm these findings, they suggest that the lipid changes observed in other studies might be due to body composition or activity changes, pharmacological rather than physiological actions or other confounders.

\section{Vascular reactivity and atherosclerotic plaque}

Experimental evidence in men rendered hypogonadal for treatment of prostate cancer suggests that low dose oral E2 add-back beneficially reduces responses to vasoconstrictors and enhances basal endothelial nitric oxide production (141). Observational data are inconclusive as to whether E2 has effects on atherosclerosis progression in men $(142,143)$.

In summary, the data suggest that the metabolically beneficial effects of testosterone on body composition are mediated via aromatization of E2 to limit adiposity, including VAT, but that the anabolic effects of testosterone on muscle mass are largely a direct effect via AR signaling. 
With respect to sex steroid-mediated beneficial effects on insulin sensitivity and glucose metabolism, experiments in male rodents and men indicate that these are, at least in part, mediated via E2 signaling in multiple metabolically active tissues. Inferences on effects on lipids and atherosclerosis are limited due to the lack of appropriately designed studies.

\section{Brain}

\section{Antenatal effects on brain structure and gender- related behavior}

Brain structure and physiology, and resultant cognition and behavior, are sexually dimorphic. The greatest distinctions pertain to structures and behaviors relevant to reproduction. These differences are attributable to differences in gonadal hormone secretion, and the effects of sex chromosome-encoded genes $(144,145,146)$.

In mammalian brain development, the default phenotype is considered to be female, with masculinization dependent on time-critical exposure (prenatal in primates, early postnatal in rodents) to sex steroids from the fetal testis (147). In rodents (148), and several other animal species (146), perinatal, gonadal testosterone-induced masculinization of the brain, defined by subsequent male-typical sexual behavior in adulthood, is aromatization dependent. The male fetus has higher brain E2 concentrations than the female because uniquely in the male, significant gonadal steroid production occurs prenatally (147). Brain E2, locally formed from gonadal testosterone, is responsible for un-methylating epigenetically repressed masculinizing genes (149) leading to brain masculinization.

Observations in humans suggest that testosterone, acting via the $A R$, is important in male gender development while any aromatization-dependent effects are less important (146). Unlike in rams, in which AI treatment during gestation disrupted normal male copulatory behavior (150), men with congenital aromatase deficiency, where reported, have male gender identity and heterosexual orientation $(47,51)$. Conversely, XY women with CAIS have a female gender identity despite elevated serum testosterone and E2 concentrations, demonstrating that AR-mediated actions are important in human brain masculinization (151). Furthermore, the single reported male lacking a functional ER $\alpha$ had a male gender identity and heterosexual orientation suggesting that ER $\alpha$ lacks an important role in human brain masculinization (35). However, biological mechanisms contributing to gender identity and sexual orientation in humans are obscured by psychological and social factors.

\section{Cognition}

Few relevant, appropriately controlled intervention studies exist in men in which the cognitive effects of testosterone and E2 can be delineated. In two small $(n=25-27)$ shortterm randomized trials of oral E2 versus placebo in older men receiving GnRH analogs for prostate cancer, E2 did not improve cognition in the specific domains tested $(152,153)$. Testosterone treatment of older men with mildly low testosterone and mild memory impairment was ineffective at improving cognition over 12 months (154).

In summary, while E2, acting locally, is critical for brain masculinization during development in rodents, in men, brain masculinization appears to track more closely with testosterone signaling via the AR, although data are limited. Whether sex steroids have effects on cognition is not clear.

\section{Vasomotor stability}

The profound sex steroid deficiency induced by ADT with GnRH analogs produces vasomotor symptoms (VMS) in the majority of men (155). In men, as in perimenopausal women, E2 withdrawal is the mediator of this effect. In women E2 withdrawal has been shown to cause release of hypothalamic neurokinin $\mathrm{B}$, a paracrine regulator of heat dissipation effectors (156). In Finkelstein's paradigm of experimental testosterone and E2 depletion in young men with differential add-back of testosterone with or without $\mathrm{AI}$, men receiving AI had a greater incidence of VMS, and even supraphysiologic serum testosterone concentrations were unable to prevent hot flushes if serum E2 remained $<37 \mathrm{pmol} / \mathrm{L}$ (157). In a preliminary report of an ongoing RCT comparing two modes of ADT for prostate cancer, highdose transdermal E2 versus standard GnRH analog therapy, men in the E2 arm had a lower incidence of hot flushes at 6 months (8 vs 46\%) (53). Finally, in a 4-week RCT, low-dose transdermal E2 add-back in men receiving GnRH analog therapy, reduced hot flush frequency-severity scores (104).

\section{Effects of excess E2 in men}

Excess exposure to estrogens in men can cause gynecomastia, hypogonadotropic hypogonadism, and, if the exposure is pre-pubertal, premature epiphyseal closure 
leading to short stature. This phenotype occurs in the rare, autosomal dominant, aromatase excess syndrome that results from subchromosomal rearrangements that enhance aromatase transcription. (158). The first rearrangements were described in 2003 (159) but cases of familial gynecomastia, likely due to this syndrome have been noted since antiquity (160).

Gynecomastia is the most consistent effect of excess exposure to estrogens in boys and men. In addition to the aromatase excess syndrome, gynecomastia has been described in cases of estrogen-secreting testicular tumors (161) and Sertoli cell proliferation in Peutz Jegher Syndrome (162), excess aromatase expression by hepatocellular carcinoma (163), occupational exposures, abuse of aromatizable androgenic steroids and intentional pharmacological use of estrogens including in transgender women and in men with prostate cancer (164). Gynecomastia is also seen without absolute estrogen excess. Male breast tissue expresses both ER and AR. In females, estrogens stimulate breast tissue, whereas androgens inhibit it (165). This understanding has been extrapolated to men (166). Gynecomastia can occur in circumstances where there is absolute androgen deficiency or where the ratio of circulating free testosterone to free E2 is reduced (164). Examples of the latter include conditions in which SHBG is increased such as thyrotoxicosis or aging (because SHBG binds testosterone more avidly than E2, SHBG elevation reduces free testosterone more than it does free E2) (167).

Klinefelter syndrome commonly causes gynecomastia (168). It has traditionally been considered a condition of absolute excess circulating E2. However, a recent metaanalysis has reported that this association was driven by studies using inaccurate assay technologies and is not present if only studies using high-quality E2 assays with sufficient accuracy in the low male range are considered (169). In this analysis, men with Klinefelter syndrome did have an increased circulating E2/T ratio, suggesting an increase in aromatization of available testosterone, the mechanism of which is not established.

Since the 1940s, high doses of synthetic oral estrogens and parenteral E2 have been used to induce profound hypogonadotrophic hypogonadism as a way of controlling locally advanced and metastatic prostate cancer. While the use of oral estrogens has stopped because of the high risk of thrombosis caused by upregulation of hepatic clotting factors by the first-pass metabolism or these estrogens, there is ongoing interest in high-dose parenteral E2 which does not have this effect (170). Other than gynecomastia, this treatment appears to be well tolerated and safe, and may prevent skeletal fracture and vasomotor symptoms associated with castration using GnRH agonists or surgery.

\section{Endocrine-disrupting chemicals}

The Endocrine Society defines an endocrine-disrupting chemical (EDC) as an 'exogenous chemical or mixture of chemicals, that interferes with any aspect of hormone action' (171). Many EDCs, such as bisphenol A, p, $\mathrm{p}^{\prime}$ dichlorodiphenyltrichloroethane (DDT, now banned), perfluorooctanoic acid (PFOA), and polychlorinated biphenyls (PCBs, now banned) bind to and activate ERs. Pre- and perinatal exposure to some of these EDCs, and others, have obesogenic, diabetogenic and reproductive effects in rodent studies and there is epidemiological evidence to support similar effects in humans (6). However, causation in humans has not been proven and EDCs can act through diverse mechanisms, including inhibition of androgen production and action, and direct toxic effects on endocrine and reproductive tissues. Therefore, it is impossible at present to isolate particular estrogenic effects of particular EDCs that are responsible for any particular clinical effect in men.

\section{Tissues in which androgen action is independent of aromatization}

In certain tissues, AR-mediated actions are clearly predominant. The in utero development of male external genitalia is AR mediated. Micropenis and hypospadias can occur in XY male infants with partial androgen insensitivity syndrome, and topical DHT, which is not aromatized, can produce penile growth (172). The higher male reference range for hemoglobin reflects the impact of androgen action on erythropoiesis. The mechanisms appear to be via AR-mediated reduction in hepatic hepcidin production, thus increasing iron availability for red cell production (173). Male-pattern body hair growth is also AR mediated, illustrated by the efficacy of $5 \alpha$-reductase inhibitors for treating androgenic alopecia (174).

\section{Clinical implications of E2 physiology in men}

Knowledge that E2 has important physiological roles in men has clinical applications. Firstly, standard therapy in hypogonadal men should be replacement with $\mathrm{T}$ (175), and not with non-aromatizable androgens, selective androgen 
receptor modulators or AIs to enhance endogenous testosterone production. These latter approaches do not correct the deficiency of estrogen action. Moreover, AIs require hypothalamic-pituitary responsiveness and are not effective in secondary organic hypogonadism or indeed in primary organic hypogonadism where circulating gonadotrophins are already high. In a 12-month RCT of AI therapy in older symptomatic men with low serum testosterone, BMD declined in those treated with AI despite increases in serum testosterone (102). Similar negative effects on BMD have been shown with DHT (32). AIs do have off-label clinical roles in boys with aromatase excess syndrome, precocious puberty due to testotoxicosis, and possibly idiopathic short stature, in which cases they appear to improve adult height (176). AIs and antiestrogens are also clinically useful in boys and men with gynecomastia due to E2 excess (177). However, concerns over skeletal safety of AIs in boys and men remain (176).

The clinical utility of selective estrogen receptor modulators (SERMs) in middle aged and older men with low testosterone is also under investigation (reviewed in (178)). Like AIs, SERMs can enhance endogenous testosterone production in men with preserved hypothalamic-pituitary responsiveness, but, in contrast to AIs, have some ER agonistic activity in somatic tissues such as the skeleton. Clinical trials to date however have been relatively small, short term and have not been designed to provide definitive evidence for clinical use (178). Furthermore, limited data suggest that the SERM, raloxifene, is an inadequate substitute for $\mathrm{E} 2$ when skeletal maturity has not yet been attained. Unlike subsequent transdermal E2 treatment, 12 months of raloxifene proved ineffective in fusing epiphyses in a young man with congenital aromatase deficiency (179). Forearm BMD improved in association with raloxifene treatment, but bone age did not advance.

Secondly, there are potential roles for E2 treatment in men requiring $\mathrm{ADT}$ for prostate cancer currently under investigation, either in the form of high-dose transdermal E2 as the method of achieving medical castration or as low-dose transdermal add-back to mitigate vasomotor symptoms and bone and metabolic side effects of GnRH analog therapy (170). Some clinical evidence already suggests E2 therapy is effective for vasomotor symptoms in men undergoing such therapy (180).

Thirdly, measurement of serum E2 concentration in the clinic, ideally with mass spectrometry, is useful in the evaluation of possible E2 excess $(177,181)$ and in differentiating the rare causes of deficient E2 action leading to persistent linear growth, delayed bone age and osteoporosis. This differential includes estrogen resistance, aromatase deficiency and rare combined defects of steroid synthesis (182).

At present, serum E2 measurement should not be part of the routine evaluation of clinical conditions such as hypogonadism or osteoporosis because there is no evidence that E2 measurements provide clinically actionable information beyond that of circulating testosterone. Access to validated gold standard mass spectrometry E2 measurement techniques for routine clinical use is still limited for many clinicians, and measurement by immunoassay is highly inaccurate and tends to overestimate E2 at the low serum concentrations present in men (183). Even if circulating E2 can be accurately measured, because $\mathrm{E} 2 \mathrm{in}$ men is produced locally and diffusely in aromatase-containing tissues, and acts in a paracrine fashion, it is unclear to what extent serum E2 concentrations reflect sufficiency of estrogenic effects in any particular tissue. Serum E2 thresholds establishing sufficiency of estrogen action in various tissues have been proposed (170). Clearly however, given the importance of E2 in male health, further studies, using increasingly available mass spectrometry assays, are needed to define the utility of serum E2 measurements in clinical practice.

\section{Conclusion}

Recent evidence has demonstrated that many biological actions historically attributed to testosterone are instead, at least in part, mediated by its aromatization product E2. The data are strongest for effects on bone, fat mass, insulin resistance and VMS. The relevance of these data is that clinically efficacious treatment of male hypogonadism is best achieved with testosterone, which provides 'three hormones in one' - testosterone, DHT, E2. Conversely, this evidence raises caution regarding the use of selective androgen receptor modulators, nonaromatizable androgens and AIs for male hypogonadism, and emphasizes the need for better understanding of the tissue-specific effects of SERMs, which are also used off label by some practitioners for this purpose. They also suggest that E2, either as sole ADT or as add-back to conventional GnRH analog-based ADT, may be a promising treatment to mitigate some of the adverse effects of ADT given to men with prostate cancer. Most current studies in men are relatively small, short term, and the design of experimental studies does not always recapitulate physiology. More research is needed to better 
understand the relative roles of testosterone versus E2 in somatic and reproductive studies and to dissect the relative biologic roles of circulating versus locally produced E2.

\section{Declaration of interest}

Mathis Grossmann has received research funding from Bayer Pharma, Novartis, Weight Watchers, Lilly and speaker's honoraria from Besins Healthcare and Otsuka. Nicholas Russell has nothing to disclose.

\section{Funding}

This work was supported by the National Health and Research Council of Australia (NHMRC) grants 1099173 and 1062073.

\section{Acknowledgements}

Nicholas Russell is supported by an Australian Government Research Higher Degree Scholarship.

\section{References}

1 Fee AR, Marrian GF \& Parkes AS. The significance of the occurrence of oestrin in male urine. Journal of Physiology 192967 377-382. (https://doi.org/10.1113/jphysiol.1929.sp002579)

2 Goldzieher JW \& Roberts IS. Identification of estrogen in the human testis. Journal of Clinical Endocrinology and Metabolism 195212 143-150. (https://doi.org/10.1210/jcem-12-2-143)

3 Steinach E \& Kun H. Transformation of male sex hormones into a substance with the action of a female hormone. Lancet 1937230 845. (https://doi.org/10.1016/S0140-6736(00)88745-0)

4 Ghosh D, Griswold J, Erman M \& Pangborn W. Structural basis for androgen specificity and oestrogen synthesis in human aromatase. Nature 2009457 219-223. (https://doi.org/10.1038/nature07614)

5 Baker ME. What are the physiological estrogens? Steroids $2013 \mathbf{7 8}$ 337-340. (https://doi.org/10.1016/j.steroids.2012.12.011)

6 Gore AC, Chappell VA, Fenton SE, Flaws JA, Nadal A, Prins GS, Toppari J \& Zoeller RT. EDC-2: the Endocrine Society's second scientific statement on endocrine-disrupting chemicals. Endocrine Reviews 201536 E1-E150. (https://doi.org/10.1210/er.2015-1010)

7 Kelch RP, Jenner MR, Weinstein R, Kaplan SL \& Grumbach MM. Estradiol and testosterone secretion by human, simian, and canine testes, in males with hypogonadism and in male pseudohermaphrodites with the feminizing testes syndrome. Journal of Clinical Investigation 197251 824-830. (https://doi.org/10.1172/JCI106877)

8 Longcope C, Kato T \& Horton R. Conversion of blood androgens to estrogens in normal adult men and women. Journal of Clinical Investigation 196948 2191-2201. (https://doi.org/10.1172/ JCI106185)

9 Longcope C, Pratt JH, Schneider SH \& Fineberg SE. Aromatization of androgens by muscle and adipose tissue in vivo. Journal of Clinical Endocrinology and Metabolism 197846 146-152. (https://doi. org/10.1210/jcem-46-1-146)

10 Hart RJ, Doherty DA, McLachlan RI, Walls ML, Keelan JA, Dickinson JE, Skakkebaek NE, Norman RJ \& Handelsman DJ. Testicular function in a birth cohort of young men. Human Reproduction 201530 2713-2724. (https://doi.org/10.1093/humrep/dev244)

11 Sartorius G, Spasevska S, Idan A, Turner L, Forbes E, Zamojska A, Allan CA, Ly LP, Conway AJ, McLachlan RI et al. Serum testosterone, dihydrotestosterone and estradiol concentrations in older men self-reporting very good health: the healthy man study. Clinical Endocrinology 201277 755-763. (https://doi.org/10.1111/j.13652265.2012.04432.x)
12 Martel C, Rhéaume E, Takahashi M, Trudel C, Couët J, LuuThe V, Simard J \& Labrie F. Distribution of 17beta-hydroxysteroid dehydrogenase gene expression and activity in rat and human tissues. Journal of Steroid Biochemistry and Molecular Biology 199241 597-603. (https://doi.org/10.1016/0960-0760(92)90390-5)

13 Fishman J, Bradlow HL \& Gallagher TF. Oxidative metabolism of estradiol. Journal of Biological Chemistry 1960235 3104-3107.

14 Yamazaki H, Shaw PM, Guengerich FP \& Shimada T. Roles of cytochromes P450 1A2 and 3A4 in the oxidation of estradiol and estrone in human liver microsomes. Chemical Research in Toxicology 199811 659-665. (https://doi.org/10.1021/tx970217f)

15 Cribb AE, Knight MJ, Dryer D, Guernsey J, Hender K, Tesch M \& Saleh TM. Role of polymorphic human cytochrome P450 enzymes in estrone oxidation. Cancer Epidemiology, Biomarkers and Prevention 200615 551-558. (https://doi.org/10.1158/1055-9965.EPI-05-0801)

16 Ziegler RG, Fuhrman BJ, Moore SC \& Matthews CE. Epidemiologic studies of estrogen metabolism and breast cancer. Steroids 201599 67-75. (https://doi.org/10.1016/j.steroids.2015.02.015)

17 Kuiper GG, Carlsson B, Grandien K, Enmark E, Häggblad J, Nilsson S \& Gustafsson JA. Comparison of the ligand binding specificity and transcript tissue distribution of estrogen receptors alpha and beta. Endocrinology 1997138 863-870. (https://doi.org/10.1210/ endo.138.3.4979)

18 Song WC. Biochemistry and reproductive endocrinology of estrogen sulfotransferase. Annals of the New York Academy of Sciences 2001948 43-50. (https://doi.org/10.1111/j.1749-6632.2001.tb03985.x)

19 Moore JT, McKee DD, Slentz-Kesler K, Moore LB, Jones SA, Horne EL, Su JL, Kliewer SA, Lehmann JM \& Willson TM. Cloning and characterization of human estrogen receptor beta isoforms. Biochemical and Biophysical Research Communications 1998247 75-78. (https://doi.org/10.1006/bbrc.1998.8738)

20 Revankar CM, Cimino DF, Sklar LA, Arterburn JB \& Prossnitz ER. A transmembrane intracellular estrogen receptor mediates rapid cell signaling. Science 2005307 1625-1630. (https://doi.org/10.1126/ science.1106943)

21 Cooke PS, Nanjappa MK, Ko C, Prins GS \& Hess RA. Estrogens in male physiology. Physiological Reviews 201797 995-1043. (https:// doi.org/10.1152/physrev.00018.2016)

22 Heldring N, Pike A, Andersson S, Matthews J, Cheng G, Hartman J, Tujague M, Ström A, Treuter E, Warner M et al. Estrogen receptors: how do they signal and what are their targets. Physiological Reviews 200787 905-931. (https://doi.org/10.1152/physrev.00026.2006)

23 Bolamperti S, Mrak E, Moro G, Sirtori P, Fraschini G, Guidobono F, Rubinacci A \& Villa I. 17 $\beta$-Estradiol positively modulates growth hormone signaling through the reduction of SOCS2 negative feedback in human osteoblasts. Bone 201355 84-92. (https://doi. org/10.1016/j.bone.2013.03.016)

24 Hammes A, Andreassen TK, Spoelgen R, Raila J, Hubner N, Schulz H, Metzger J, Schweigert FJ, Luppa PB, Nykjaer A et al. Role of endocytosis in cellular uptake of sex steroids. Cell 2005122 751-762. (https://doi.org/10.1016/j.cell.2005.06.032)

25 Luu-The V \& Labrie F. The intracrine sex steroid biosynthesis pathways. Progress in Brain Research 2010181 177-192. (https://doi. org/10.1016/S0079-6123(08)81010-2)

26 Hrabovszky E, Kalló I, Szlávik N, Keller E, Merchenthaler I \& Liposits Z. Gonadotropin-releasing hormone neurons express estrogen receptor-beta. Journal of Clinical Endocrinology and Metabolism 200792 2827-2830. (https://doi.org/10.1210/jc.2006-2819)

27 Mittelman-Smith MA, Williams H, Krajewski-Hall SJ, Lai J, Ciofi P, McMullen NT \& Rance NE. Arcuate kisspeptin/neurokinin B/ dynorphin (KNDy) neurons mediate the estrogen suppression of gonadotropin secretion and body weight. Endocrinology 2012153 2800-2812. (https://doi.org/10.1210/en.2012-1045)

28 Finkelstein JS, O'Dea LS, Whitcomb RW \& Crowley WF. Sex steroid control of gonadotropin secretion in the human male. II. Effects of estradiol administration in normal and gonadotropin-releasing 
hormone-deficient men. Journal of Clinical Endocrinology and Metabolism 199173 621-628. (https://doi.org/10.1210/ jcem-73-3-621)

29 Rochira V, Zirilli L, Genazzani AD, Balestrieri A, Aranda C, Fabre B, Antunez P, Diazzi C, Carani C \& Maffei L. Hypothalamic-pituitarygonadal axis in two men with aromatase deficiency: evidence that circulating estrogens are required at the hypothalamic level for the integrity of gonadotropin negative feedback. European Journal of Endocrinology 2006155 513-522. (https://doi.org/10.1530/eje.1.02254)

30 Hayes FJ, Seminara SB, DeCruz S, Boepple PA \& Crowley WF. Aromatase inhibition in the human male reveals a hypothalamic site of estrogen feedback. Journal of Clinical Endocrinology and Metabolism 200085 3027-3035. (https://doi.org/10.1210/jcem.85.9.6795)

31 Pitteloud N, Dwyer AA, DeCruz S, Lee H, Boepple PA, Crowley WF \& Hayes FJ. Inhibition of luteinizing hormone secretion by testosterone in men requires aromatization for its pituitary but not its hypothalamic effects: evidence from the tandem study of normal and gonadotropin-releasing hormone-deficient men. Journal of Clinical Endocrinology and Metabolism 200893 784-791. (https://doi. org/10.1210/jc.2007-2156)

32 Idan A, Griffiths KA, Harwood DT, Seibel MJ, Turner L, Conway AJ \& Handelsman DJ. Long-term effects of dihydrotestosterone treatment on prostate growth in healthy, middle-aged men without prostate disease: a randomized, placebo-controlled trial. Annals of Internal Medicine 2010153 621-632. (https://doi.org/10.7326/0003-4819153-10-201011160-00004)

33 Boyar RM, Moore RJ, Rosner W, Aiman J, Chipman J, Madden JD, Marks JF \& Griffin JE. Studies of gonadotropin-gonadal dynamics in patients with androgen insensitivity. Journal of Clinical Endocrinology and Metabolism 197847 1116-1122. (https://doi.org/10.1210/jcem47-5-1116)

34 Hess RA, Bunick D, Lee KH, Bahr J, Taylor JA, Korach KS \& Lubahn DB. A role for oestrogens in the male reproductive system. Nature 1997390 509-512. (https://doi.org/10.1038/37352)

35 Smith EP, Boyd J, Frank GR, Takahashi H, Cohen RM, Specker B, Williams TC, Lubahn DB \& Korach KS. Estrogen resistance caused by a mutation in the estrogen-receptor gene in a man. New England Journal of Medicine 1994331 1056-1061. (https://doi.org/10.1056/ NEJM199410203311604)

36 Bernard V, Kherra S, Francou B, Fagart J, Viengchareun S, Guéchot J, Ladjouze A, Guiochon-Mantel A, Korach KS, Binart N et al. Familial multiplicity of estrogen insensitivity associated with a loss-offunction ESR1 mutation. Journal of Clinical Endocrinology and Metabolism 2017 102 93-99. (https://doi.org/10.1210/jc.2016-2749)

37 Robertson KM, O'Donnell L, Jones ME, Meachem SJ, Boon WC, Fisher CR, Graves KH, McLachlan RI \& Simpson ER. Impairment of spermatogenesis in mice lacking a functional aromatase (cyp 19) gene. PNAS 199996 7986-7991. (https://doi.org/10.1073/ pnas.96.14.7986)

38 Morishima A, Grumbach MM, Simpson ER, Fisher C \& Qin K. Aromatase deficiency in male and female siblings caused by a novel mutation and the physiological role of estrogens. Journal of Clinical Endocrinology and Metabolism 199580 3689-3698. (https://doi. org/10.1210/jcem.80.12.8530621)

39 Herrmann BL, Saller B, Janssen OE, Gocke P, Bockisch A, Sperling H, Mann K \& Broecker M. Impact of estrogen replacement therapy in a male with congenital aromatase deficiency caused by a novel mutation in the CYP19 gene. Journal of Clinical Endocrinology and Metabolism 2002 87 5476-5484. (https://doi.org/10.1210/jc.2002-020498)

40 Bouillon R, Bex M, Vanderschueren D \& Boonen S. Estrogens are essential for male pubertal periosteal bone expansion. Journal of Clinical Endocrinology and Metabolism 200489 6025-6029. (https:// doi.org/10.1210/jc.2004-0602)

41 Miedlich SU, Karamooz N \& Hammes SR. Aromatase deficiency in a male patient - case report and review of the literature. Bone 201693 181-186. (https://doi.org/10.1016/j.bone.2016.09.024)
42 Chen Z, Wang O, Nie M, Elison K, Zhou D, Li M, Jiang Y, Xia W, Meng X, Chen S et al. Aromatase deficiency in a Chinese adult man caused by novel compound heterozygous CYP19A1 mutations: effects of estrogen replacement therapy on the bone, lipid, liver and glucose metabolism. Molecular and Cellular Endocrinology 2015399 32-42. (https://doi.org/10.1016/j.mce.2014.09.016)

43 Bouchoucha N, Samara-Boustani D, Pandey AV, Bony-Trifunovic H, Hofer G, Aigrain Y, Polak M \& Flück CE. Characterization of a novel CYP19A1 (aromatase) R192H mutation causing virilization of a $46, X X$ newborn, undervirilization of the 46 ,XY brother, but no virilization of the mother during pregnancies. Molecular and Cellular Endocrinology 2014390 8-17. (https://doi.org/10.1016/j. mce.2014.03.008)

44 Baykan EK, Erdoğan M, Özen S, Darcan Ş \& Saygılı LF. Aromatase deficiency, a rare syndrome: case report. Journal of Clinical Research in Pediatric Endocrinology 20135 129-132. (https://doi.org/10.4274/ Jcrpe.970)

45 Lanfranco F, Zirilli L, Baldi M, Pignatti E, Corneli G, Ghigo E, Aimaretti G, Carani C \& Rochira V. A novel mutation in the human aromatase gene: insights on the relationship among serum estradiol, longitudinal growth and bone mineral density in an adult man under estrogen replacement treatment. Bone 200843 628-635. (https://doi.org/10.1016/j.bone.2008.05.011)

46 Carani C, Qin K, Simoni M, Faustini-Fustini M, Serpente S, Boyd J, Korach KS \& Simpson ER. Effect of testosterone and estradiol in a man with aromatase deficiency. New England Journal of Medicine 1997 337 91-95. (https://doi.org/10.1056/NEJM199707103370204)

47 Carani C, Granata ARM, Rochira V, Caffagni G, Aranda C, Antunez P \& Maffei LE. Sex steroids and sexual desire in a man with a novel mutation of aromatase gene and hypogonadism. Psychoneuroendocrinology 200530 413-417. (https://doi. org/10.1016/j.psyneuen.2004.10.004)

48 Maffei L, Murata Y, Rochira V, Tubert G, Aranda C, Vazquez M, Clyne CD, Davis S, Simpson ER \& Carani C. Dysmetabolic syndrome in a man with a novel mutation of the aromatase gene: effects of testosterone, alendronate, and estradiol treatment. Journal of Clinical Endocrinology and Metabolism 200489 61-70. (https://doi. org/10.1210/jc.2003-030313)

49 Maffei L, Rochira V, Zirilli L, Antunez P, Aranda C, Fabre B, Simone ML, Pignatti E, Simpson ER, Houssami S et al. A novel compound heterozygous mutation of the aromatase gene in an adult man: reinforced evidence on the relationship between congenital oestrogen deficiency, adiposity and the metabolic syndrome. Clinical Endocrinology 200767 218-224. (https://doi.org/10.1111/j.13652265.2007.02864.x)

50 Sinkevicius KW, Laine M, Lotan TL, Woloszyn K, Richburg JH \& Greene GL. Estrogen-dependent and -independent estrogen receptoralpha signaling separately regulate male fertility. Endocrinology 2009 150 2898-2905. (https://doi.org/10.1210/en.2008-1016)

51 Carani C, Rochira V, Faustini-Fustini M, Balestrieri A \& Granata AR. Role of oestrogen in male sexual behaviour: insights from the natural model of aromatase deficiency. Clinical Endocrinology 199951 517-524. (https://doi.org/10.1046/j.13652265.1999.00849.x)

52 Wibowo E \& Wassersug RJ. The effect of estrogen on the sexual interest of castrated males: implications to prostate cancer patients on androgen-deprivation therapy. Critical Reviews in Oncology/Hematology 201387 224-238. (https://doi.org/10.1016/j. critrevonc.2013.01.006)

53 Gilbert DC, Duong T, Kynaston HG, Alhasso AA, Cafferty FH, Rosen SD, Kanaga-Sundaram S, Dixit S, Laniado M, Madaan S et al. Quality-of-life outcomes from the Prostate Adenocarcinoma: TransCutaneous Hormones (PATCH) trial evaluating luteinising hormone-releasing hormone agonists versus transdermal oestradiol for androgen suppression in advanced prostate cancer. BJU International 2017119 667-675. (https://doi.org/10.1111/bju.13687) 
54 Finkelstein JS, Lee H, Burnett-Bowie SAM, Pallais JC, Yu EW, Borges LF, Jones BF, Barry CV, Wulczyn KE, Thomas BJ et al. Gonadal steroids and body composition, strength, and sexual function in men. New England Journal of Medicine 2013369 1011-1022. (https:// doi.org/10.1056/NEJMoa1206168)

55 Ellem SJ, Schmitt JF, Pedersen JS, Frydenberg M \& Risbridger GP. Local aromatase expression in human prostate is altered in malignancy. Journal of Clinical Endocrinology and Metabolism 200489 2434-2441. (https://doi.org/10.1210/jc.2003-030933)

56 Shapiro E, Huang H, Masch RJ, McFadden DE, Wilson EL \& Wu XR. Immunolocalization of estrogen receptor alpha and beta in human fetal prostate. Journal of Urology 2005174 2051-2053. (https://doi. org/10.1097/01.ju.0000176472.90432.5b)

57 Hu WY, Shi GB, Lam HM, Hu DP, Ho SM, Madueke IC, Kajdacsy-Balla A $\&$ Prins GS. Estrogen-initiated transformation of prostate epithelium derived from normal human prostate stem-progenitor cells. Endocrinology 2011152 2150-2163. (https://doi.org/10.1210/en.2010-1377)

58 Prins GS \& Ho SM. Early-life estrogens and prostate cancer in an animal model. Journal of Developmental Origins of Health and Disease 20101 365-370. (https://doi.org/10.1017/S2040174410000577)

59 Dias JP, Melvin D, Shardell M, Ferrucci L, Chia CW, Gharib M, Egan JM \& Basaria S. Effects of transdermal testosterone gel or an aromatase inhibitor on prostate volume in older men. Journal of Clinical Endocrinology and Metabolism 2016101 1865-1871. (https:// doi.org/10.1210/jc.2016-1111)

60 Risbridger GP, Ellem SJ \& McPherson SJ. Estrogen action on the prostate gland: a critical mix of endocrine and paracrine signaling. Journal of Molecular Endocrinology 200739 183-188. (https://doi. org/10.1677/JME-07-0053)

61 Chan QKY, Lam HM, Ng CF, Lee AYY, Chan ESY, Ng HK, Ho SM \& Lau KM. Activation of GPR30 inhibits the growth of prostate cancer cells through sustained activation of ERK1/2, c-jun/c-fosdependent upregulation of p21, and induction of G(2) Cell-cycle arrest. Cell Death and Differentiation 201017 1511-1523. (https://doi. org/10.1038/cdd.2010.20)

62 Ozten N, Vega K, Liehr J, Huang X, Horton L, Cavalieri EL, Rogan EG $\&$ Bosland MC. Role of estrogen in androgen-induced prostate carcinogenesis in NBL rats. Hormones and Cancer 201927 1-12. (https://doi.org/10.1007/s12672-019-00360-7)

63 Santen RJ, Petroni GR, Fisch MJ, Myers CE, Theodorescu D $\&$ Cohen RB. Use of the aromatase inhibitor anastrozole in the treatment of patients with advanced prostate carcinoma. Cancer 200192 2095-2101. (https://doi.org/10.1002/10970142(20011015)92:8<2095::AID-CNCR1550>3.0.CO;2-Y)

64 Byar DP. The Veterans Administration Cooperative Urological Research Group's studies of cancer of the prostate. Cancer 197332 1126-1130. (https://doi.org/10.1002/10970142(197311)32:5<1126::AID-CNCR2820320518>3.0.CO;2-C)

65 Langley RE, Cafferty FH, Alhasso AA, Rosen SD, Sundaram SK, Freeman SC, Pollock P, Jinks RC, Godsland IF, Kockelbergh R et al. Cardiovascular outcomes in patients with locally advanced and metastatic prostate cancer treated with luteinising-hormonereleasing-hormone agonists or transdermal oestrogen: the randomised, phase 2 MRC PATCH trial. Lancet: Oncology 201314 306-316. (https://doi.org/10.1016/S1470-2045(13)70025-1)

66 Rochira V, Zirilli L, Maffei L, Premrou V, Aranda C, Baldi M, Ghigo E, Aimaretti G, Carani C \& Lanfranco F. Tall stature without growth hormone: four male patients with aromatase deficiency. Journal of Clinical Endocrinology and Metabolism 201095 1626-1633. (https:// doi.org/10.1210/jc.2009-1743)

67 Birzniece V \& Ho KKY. Sex steroids and the GH axis: implications for the management of hypopituitarism. Best Practice and Research: Clinical Endocrinology and Metabolism 201731 59-69. (https://doi. org/10.1016/j.beem.2017.03.003)

68 Roelfsema F, Yang RJ, Takahashi PY, Erickson D, Bowers CY \& Veldhuis JD. Aromatized estrogens amplify nocturnal growth hormone secretion in testosterone-replaced older hypogonadal men. Journal of Clinical Endocrinology and Metabolism 2018103 4419-4427. (https://doi.org/10.1210/jc.2018-00755)

69 Avtanski D, Novaira HJ, Wu S, Romero CJ, Kineman R, Luque RM, Wondisford F \& Radovick S. Both estrogen receptor $\alpha$ and $\beta$ stimulate pituitary GH gene expression. Molecular Endocrinology 201428 40-52. (https://doi.org/10.1210/me.2013-1245)

70 Leung KC, Doyle N, Ballesteros M, Sjogren K, Watts CKW, Low TH, Leong GM, Ross RJM \& Ho KKY. Estrogen inhibits GH signaling by suppressing GH-induced JAK2 phosphorylation, an effect mediated by SOCS-2. PNAS 2003100 1016-1021. (https://doi.org/10.1073/ pnas.0337600100)

71 Weissberger AJ, Ho KK \& Lazarus L. Contrasting effects of oral and transdermal routes of estrogen replacement therapy on 24-hour growth hormone (GH) secretion, insulin-like growth factor I, and GH-binding protein in postmenopausal women. Journal of Clinical Endocrinology and Metabolism 199172 374-381. (https://doi. org/10.1210/jcem-72-2-374)

72 Riggs BL, Khosla S \& Melton LJ. Sex steroids and the construction and conservation of the adult skeleton. Endocrine Reviews 200223 279-302. (https://doi.org/10.1210/edrv.23.3.0465)

73 Weitzmann MN \& Pacifici R. Estrogen deficiency and bone loss: an inflammatory tale. Journal of Clinical Investigation $2006 \mathbf{1 1 6}$ 1186-1194. (https://doi.org/10.1172/JCI28550)

74 Khosla S \& Monroe DG. Regulation of bone metabolism by sex steroids. Cold Spring Harbor Perspectives in Medicine $2018 \mathbf{8}$ a031211. (https://doi.org/10.1101/cshperspect.a031211)

75 Windahl SH, Saxon L, Börjesson AE, Lagerquist MK, Frenkel B, Henning P, Lerner UH, Galea GL, Meakin LB, Engdahl C et al. Estrogen receptor- $\alpha$ is required for the osteogenic response to mechanical loading in a ligand-independent manner involving its activation function 1 but not 2. Journal of Bone and Mineral Research 201328 291-301. (https://doi.org/10.1002/jbmr.1754)

76 Juul A. The effects of oestrogens on linear bone growth. Human Reproduction Update 20017 303-313. (https:/doi.org/10.1093/ humupd/7.3.303)

77 Seeman E. Pathogenesis of bone fragility in women and men. Lancet 2002359 1841-1850. (https://doi.org/10.1016/S01406736(02)08706-8)

78 Iuliano-Burns S, Hopper J \& Seeman E. The age of puberty determines sexual dimorphism in bone structure: a male/female co-twin control study. Journal of Clinical Endocrinology and Metabolism 200994 1638-1643. (https://doi.org/10.1210/jc.2008-1522)

79 Börjesson AE, Lagerquist MK, Windahl SH \& Ohlsson C. The role of estrogen receptor $\alpha$ in the regulation of bone and growth plate cartilage. Cellular and Molecular Life Sciences $2013704023-4037$. (https://doi.org/10.1007/s00018-013-1317-1)

80 Zachmann M, Prader A, Sobel EH, Crigler JF, Ritzen EM, Atarés M \& Ferrandez A. Pubertal growth in patients with androgen insensitivity: indirect evidence for the importance of estrogens in pubertal growth of girls. Journal of Pediatrics $1986 \mathbf{1 0 8}$ 694-697. (https://doi. org/10.1016/S0022-3476(86)81043-5)

81 Caruso-Nicoletti M, Cassorla F, Skerda M, Ross JL, Loriaux DL \& Cutler GB. Short term, low dose estradiol accelerates ulnar growth in boys. Journal of Clinical Endocrinology and Metabolism 198561 896-898. (https://doi.org/10.1210/jcem-61-5-896)

82 Herrmann BL, Janssen OE, Hahn S, Broecker-Preuss M \& Mann K. Effects of estrogen replacement therapy on bone and glucose metabolism in a male with congenital aromatase deficiency. Hormone and Metabolic Research 200537 178-183. (https://doi. org/10.1055/s-2005-861292)

83 Almeida M, Laurent MR, Dubois V, Claessens F, O'Brien CA, Bouillon R, Vanderschueren D \& Manolagas SC. Estrogens and androgens in skeletal physiology and pathophysiology. Physiological Reviews 201797 135-187. (https://doi.org/10.1152/ physrev.00033.2015) 
84 Jansson JO, Edén S \& Isaksson O. Sites of action of testosterone and estradiol on longitudinal bone growth. American Journal of Physiology 1983244 E135-E140. (https://doi.org/10.1152/ ajpendo.1983.244.2.E135)

85 Ottesen AM, Aksglaede L, Garn I, Tartaglia N, Tassone F, Gravholt CH, Bojesen A, Sørensen K, Jørgensen N, Rajpert-De Meyts E et al. Increased number of sex chromosomes affects height in a nonlinear fashion: a study of 305 patients with sex chromosome aneuploidy. American Journal of Medical Genetics: Part A 2010 152A 1206-1212. (https://doi.org/10.1002/ajmg.a.33334)

86 Dahlgren A, Lundmark P, Axelsson T, Lind L \& Syvänen AC. Association of the estrogen receptor 1 (ESR1) gene with body height in adult males from two Swedish population cohorts. PLOS ONE 2008 3 e1807. (https://doi.org/10.1371/journal.pone.0001807)

87 Yang TL, Xiong DH, Guo Y, Recker RR \& Deng HW. Association analyses of CYP19 gene polymorphisms with height variation in a large sample of Caucasian nuclear families. Human Genetics $2006 \mathbf{1 2 0}$ 119-125. (https://doi.org/10.1007/s00439-006-0199-9)

88 Wood AR, Esko T, Yang J, Vedantam S, Pers TH, Gustafsson S, Chu AY, Estrada K, Luan J, Kutalik Z et al. Defining the role of common variation in the genomic and biological architecture of adult human height. Nature Genetics 201446 1173-1186. (https://doi.org/10.1038/ ng.3097)

89 Smith EP, Specker B, Bachrach BE, Kimbro KS, Li XJ, Young MF, Fedarko NS, Abuzzahab MJ, Frank GR, Cohen RM et al. Impact on bone of an estrogen receptor-alpha gene loss of function mutation. Journal of Clinical Endocrinology and Metabolism 200893 3088-3096. (https://doi.org/10.1210/jc.2007-2397)

90 Falahati-Nini A, Riggs BL, Atkinson EJ, O'Fallon WM, Eastell R \& Khosla S. Relative contributions of testosterone and estrogen in regulating bone resorption and formation in normal elderly men. Journal of Clinical Investigation 2000106 1553-1560. (https://doi. org/10.1172/JCI10942)

91 Hamilton EJ, Ghasem-Zadeh A, Gianatti E, Lim Joon D, Bolton D, Zebaze R, Seeman E, Zajac JD \& Grossmann M. Structural decay of bone microarchitecture in men with prostate cancer treated with androgen deprivation therapy. Journal of Clinical Endocrinology and Metabolism 201095 E456-E463. (https://doi.org/10.1210/jc.2010-0902)

92 Callewaert F, Venken K, Kopchick JJ, Torcasio A, van Lenthe GH, Boonen S \& Vanderschueren D. Sexual dimorphism in cortical bone size and strength but not density is determined by independent and time-specific actions of sex steroids and IGF-1: evidence from pubertal mouse models. Journal of Bone and Mineral Research 201025 617-626. (https://doi.org/10.1359/jbmr.090828)

93 Sims NA, Brennan K, Spaliviero J, Handelsman DJ \& Seibel MJ. Perinatal testosterone surge is required for normal adult bone size but not for normal bone remodeling. American Journal of Physiology: Endocrinology and Metabolism 2006290 E456-E462. (https://doi. org/10.1152/ajpendo.00311.2005)

94 Marcus R, Leary D, Schneider DL, Shane E, Favus M \& Quigley CA. The contribution of testosterone to skeletal development and maintenance: lessons from the androgen insensitivity syndrome. Journal of Clinical Endocrinology and Metabolism 200085 1032-1037. (https://doi.org/10.1210/jcem.85.3.6428)

95 Lorentzon M, Swanson C, Andersson N, Mellström D \& Ohlsson C. Free testosterone is a positive, whereas free estradiol is a negative, predictor of cortical bone size in young Swedish men: the GOOD study. Journal of Bone and Mineral Research 200520 1334-1341. (https://doi.org/10.1359/JBMR.050404)

96 Chen Z, Tao S, Gao Y, Zhang J, Hu Y, Mo L, Kim ST, Yang X, Tan A, Zhang $\mathrm{H}$ et al. Genome-wide association study of sex hormones, gonadotropins and sex hormone-binding protein in Chinese men. Journal of Medical Genetics $20135 \mathbf{5 0} 794-801$. (https://doi. org/10.1136/jmedgenet-2013-101705)

97 Eriksson AL, Perry JRB, Coviello AD, Delgado GE, Ferrucci L, Hoffman AR, Huhtaniemi IT, Ikram MA, Karlsson MK, Kleber ME et al. Genetic determinants of circulating estrogen levels and evidence of a causal effect of estradiol on bone density in men. Journal of Clinical Endocrinology and Metabolism 2018103 991-1004. (https://doi.org/10.1210/jc.2017-02060)

98 Lorentzon M, Swanson C, Eriksson AL, Mellström D \& Ohlsson C. Polymorphisms in the aromatase gene predict areal BMD as a result of affected cortical bone size: the GOOD study. Journal of Bone and Mineral Research 200621 332-339. (https://doi.org/10.1359/ JBMR.051026)

99 LeBlanc ES, Nielson CM, Marshall LM, Lapidus JA, Barrett-Connor E, Ensrud KE, Hoffman AR, Laughlin G, Ohlsson C, Orwoll ES et al. The effects of serum testosterone, estradiol, and sex hormone binding globulin levels on fracture risk in older men. Journal of Clinical Endocrinology and Metabolism 200994 3337-3346. (https://doi. org/10.1210/jc.2009-0206)

100 Mellström D, Vandenput L, Mallmin H, Holmberg AH, Lorentzon M, Oden A, Johansson H, Orwoll ES, Labrie F, Karlsson MK et al. Older men with low serum estradiol and high serum SHBG have an increased risk of fractures. Journal of Bone and Mineral Research 2008 23 1552-1560. (https://doi.org/10.1359/jbmr.080518)

101 Argoud T, Boutroy S, Claustrat B, Chapurlat R \& Szulc P. Association between sex steroid levels and bone microarchitecture in men: the STRAMBO study. Journal of Clinical Endocrinology and Metabolism 2014 99 1400-1410. (https://doi.org/10.1210/jc.2013-3233)

102 Burnett-Bowie SAM, McKay EA, Lee H \& Leder BZ. Effects of aromatase inhibition on bone mineral density and bone turnover in older men with low testosterone levels. Journal of Clinical Endocrinology and Metabolism 200994 4785-4792. (https://doi. org/10.1210/jc.2009-0739)

103 Finkelstein JS, Lee H, Leder BZ, Burnett-Bowie SAM, Goldstein DW, Hahn CW, Hirsch SC, Linker A, Perros N, Servais AB et al. Gonadal steroid-dependent effects on bone turnover and bone mineral density in men. Journal of Clinical Investigation 2016126 1114-1125. (https://doi.org/10.1172/JCI84137)

104 Russell N, Hoermann R, Cheung AS, Ching M, Zajac JD, Handelsman DJ \& Grossmann M. Short-term effects of transdermal estradiol in men undergoing androgen deprivation therapy for prostate cancer: a randomized placebo-controlled trial. European Journal of Endocrinology $2018 \mathbf{1 7 8} 565-576$. (https://doi.org/10.1530/ EJE-17-1072)

105 Langley RE, Kynaston HG, Alhasso AA, Duong T, Paez EM, Jovic G, Scrase CD, Robertson A, Cafferty F, Welland A et al. A randomised comparison evaluating changes in bone mineral density in advanced prostate cancer: luteinising hormone-releasing hormone agonists versus transdermal oestradiol. European Urology 201669 1016-1025. (https://doi.org/10.1016/j.eururo.2015.11.030)

106 Roddam AW, Appleby P, Neale R, Dowsett M, Folkerd E, Tipper S, Allen NE \& Key TJ. Association between endogenous plasma hormone concentrations and fracture risk in men and women: the EPIC-Oxford prospective cohort study. Journal of Bone and Mineral Metabolism 2009 27 485-493. (https://doi.org/10.1007/s00774-009-0060-z)

107 Kuchuk NO, van Schoor NM, Pluijm SMF, Smit JH, de Ronde W $\&$ Lips P. The association of sex hormone levels with quantitative ultrasound, bone mineral density, bone turnover and osteoporotic fractures in older men and women. Clinical Endocrinology 200767 295-303. (https://doi.org/10.1111/j.1365-2265.2007.02882.x)

108 Center JR, Nguyen TV, Sambrook PN \& Eisman JA. Hormonal and biochemical parameters and osteoporotic fractures in elderly men. Journal of Bone and Mineral Research 200015 1405-1411. (https://doi. org/10.1359/jbmr.2000.15.7.1405)

109 Meier C, Nguyen TV, Handelsman DJ, Schindler C, Kushnir MM, Rockwood AL, Meikle AW, Center JR, Eisman JA \& Seibel MJ. Endogenous sex hormones and incident fracture risk in older men: the Dubbo Osteoporosis Epidemiology Study. Archives of Internal Medicine 2008168 47-54. (https://doi.org/10.1001/ archinternmed.2007.2) 
110 Hsu B, Cumming RG, Seibel MJ, Naganathan V, Blyth FM, Bleicher K, Dave A, Le Couteur DG, Waite LM \& Handelsman DJ. Reproductive hormones and longitudinal change in bone mineral density and incident fracture risk in older men: the concord health and aging in men project. Journal of Bone and Mineral Research 201530 1701-1708. (https://doi.org/10.1002/jbmr.2493)

111 Nethander M, Vandenput L, Eriksson AL, Windahl S, FunckBrentano T \& Ohlsson C. Evidence of a causal effect of estradiol on fracture risk in men. Journal of Clinical Endocrinology and Metabolism 2019104 433-442. (https://doi.org/10.1210/jc.2018-00934)

112 Handelsman DJ, Yeap B, Flicker L, Martin S, Wittert GA \& Ly LP. Age-specific population centiles for androgen status in men. European Journal of Endocrinology 2015173 809-817. (https://doi.org/10.1530/ EJE-15-0380)

113 Rochira V, Kara E \& Carani C. The endocrine role of estrogens on human male skeleton. International Journal of Endocrinology 2015 2015 165215-165215. (https://doi.org/10.1155/2015/165215)

114 Matsumine H, Hirato K, Yanaihara T, Tamada T \& Yoshida M. Aromatization by skeletal muscle. Journal of Clinical Endocrinology and Metabolism 198663 717-720. (https://doi.org/10.1210/jcem63-3-717)

115 Ackerman GE, Smith ME, Mendelson CR, MacDonald PC \& Simpson ER. Aromatization of androstenedione by human adipose tissue stromal cells in monolayer culture. Journal of Clinical Endocrinology and Metabolism 198153 412-417. (https://doi. org/10.1210/jcem-53-2-412)

116 Pedersen SB, Bruun JM, Hube F, Kristensen K, Hauner H \& Richelsen B. Demonstration of estrogen receptor subtypes alpha and beta in human adipose tissue: influences of adipose cell differentiation and fat depot localization. Molecular and Cellular Endocrinology 2001182 27-37. (https://doi.org/10.1016/S03037207(01)00557-3)

117 Lemoine S, Granier P, Tiffoche C, Rannou-Bekono F, Thieulant ML $\&$ Delamarche P. Estrogen receptor alpha mRNA in human skeletal muscles. Medicine and Science in Sports and Exercise 200335 439-443. (https://doi.org/10.1249/01.MSS.0000053654.14410.78)

118 Dalton JT, Barnette KG, Bohl CE, Hancock ML, Rodriguez D, Dodson ST, Morton RA \& Steiner MS. The selective androgen receptor modulator GTx-024 (enobosarm) improves lean body mass and physical function in healthy elderly men and postmenopausal women: results of a double-blind, placebo-controlled phase II trial. Journal of Cachexia, Sarcopenia and Muscle 20112 153-161. (https:// doi.org/10.1007/s13539-011-0034-6)

119 Basaria S \& Bhasin S. Targeting the skeletal muscle-metabolism axis in prostate-cancer therapy. New England Journal of Medicine 2012367 965-967. (https://doi.org/10.1056/NEJMcibr1203160)

120 Bhasin S, Taylor WE, Singh R, Artaza J, Sinha-Hikim I, Jasuja R, Choi $\mathrm{H} \&$ Gonzalez-Cadavid NF. The mechanisms of androgen effects on body composition: mesenchymal pluripotent cell as the target of androgen action. Journals of Gerontology: Series A, Biological Sciences and Medical Sciences 200358 M1103-M1110. (https://doi. org/10.1093/gerona/58.12.m1103)

121 Juang PS, Peng S, Allehmazedeh K, Shah A, Coviello AD \& Herbst KL. Testosterone with dutasteride, but not anastrazole, improves insulin sensitivity in young obese men: a randomized controlled trial. Journal of Sexual Medicine 201411 563-573. (https://doi.org/10.1111/ jsm.12368)

122 Birzniece V. Hepatic actions of androgens in the regulation of metabolism. Current Opinion in Endocrinology, Diabetes, and Obesity 201825 201-208. (https://doi.org/10.1097/MED.0000000000000405)

123 Mårin P, Holmäng S, Gustafsson C, Jönsson L, Kvist H, Elander A, Eldh J, Sjöström L, Holm G \& Björntorp P. Androgen treatment of abdominally obese men. Obesity Research 19931 245-251. (https:// doi.org/10.1002/j.1550-8528.1993.tb00618.x)

124 Foryst-Ludwig A, Clemenz M, Hohmann S, Hartge M, Sprang C, Frost N, Krikov M, Bhanot S, Barros R, Morani A et al. Metabolic actions of estrogen receptor beta (ERbeta) are mediated by a negative cross-talk with PPARgamma. PLoS Genetics 20084 e1000108. (https:// doi.org/10.1371/journal.pgen.1000108)

125 Fui MNT, Dupuis P \& Grossmann M. Lowered testosterone in male obesity: mechanisms, morbidity and management. Asian Journal of Andrology 201416 223-231. (https://doi.org/10.4103/1008682X.122365)

126 Schneider G, Kirschner MA, Berkowitz R \& Ertel NH. Increased estrogen production in obese men. Journal of Clinical Endocrinology and Metabolism 197948 633-638. (https://doi.org/10.1210/jcem-48-4-633)

127 Dhindsa S, Furlanetto R, Vora M, Ghanim H, Chaudhuri A \& Dandona P. Low estradiol concentrations in men with subnormal testosterone concentrations and type 2 diabetes. Diabetes Care 2011 34 1854-1859. (https://doi.org/10.2337/dc11-0208)

128 Tajar A, Huhtaniemi IT, O'Neill TW, Finn JD, Pye SR, Lee DM, Bartfai G, Boonen S, Casanueva FFF, Forti G et al. Characteristics of androgen deficiency in late-onset hypogonadism: results from the European Male Aging Study (EMAS) Journal of Clinical Endocrinology and Metabolism 201297 1508-1516. (https://doi.org/10.1210/ jc.2011-2513)

129 Rochira V, Madeo B, Zirilli L, Caffagni G, Maffei L \& Carani C. Oestradiol replacement treatment and glucose homeostasis in two men with congenital aromatase deficiency: evidence for a role of oestradiol and sex steroids imbalance on insulin sensitivity in men. Diabetic Medicine 200724 1491-1495. (https://doi.org/10.1111/ j.1464-5491.2007.02304.x)

130 Grossmann M, Wierman ME, Angus P \& Handelsman DJ. Reproductive endocrinology of non-alcoholic fatty liver disease. Endocrine Reviews 201940 417-446. (https://doi.org/10.1210/er.201800158)

131 Barros RPA \& Gustafsson JÅ. Estrogen receptors and the metabolic network. Cell Metabolism 201114 289-299. (https://doi. org/10.1016/j.cmet.2011.08.005)

132 Ohlsson C, Hammarstedt A, Vandenput L, Saarinen N, Ryberg H, Windahl SH, Farman HH, Jansson JO, Movérare-Skrtic S, Smith U et al. Increased adipose tissue aromatase activity improves insulin sensitivity and reduces adipose tissue inflammation in male mice. American Journal of Physiology: Endocrinology and Metabolism 2017313 E450-E462. (https://doi.org/10.1152/ajpendo.00093.2017)

133 Gibb FW, Homer NZM, Faqehi AMM, Upreti R, Livingstone DE, McInnes KJ, Andrew R \& Walker BR. Aromatase inhibition reduces insulin sensitivity in healthy men. Journal of Clinical Endocrinology and Metabolism 2016101 2040-2046. (https://doi.org/10.1210/ jc.2015-4146)

134 Gagliano-Jucá T, Burak MF, Pencina KM, Li Z, Edwards RR, Travison TG \& Basaria S. Metabolic changes in androgen-deprived nondiabetic men with prostate cancer are not mediated by cytokines or aP2. Journal of Clinical Endocrinology and Metabolism 2018103 3900-3908. (https://doi.org/10.1210/jc.2018-01068)

135 Braga-Basaria M, Muller DC, Carducci MA, Dobs AS \& Basaria S. Lipoprotein profile in men with prostate cancer undergoing androgen deprivation therapy. International Journal of Impotence Research 200618 494-498. (https://doi.org/10.1038/sj.ijir.3901471)

136 Dockery F, Bulpitt CJ, Agarwal S, Donaldson M \& Rajkumar C. Testosterone suppression in men with prostate cancer leads to an increase in arterial stiffness and hyperinsulinaemia. Clinical Science 2003104 195-201. (https://doi.org/10.1042/CS20020209)

137 Moorjani S, Dupont A, Labrie F, Lupien PJ, Gagné C, Brun D, Giguère M, Bélanger A \& Cusan L. Changes in plasma lipoproteins during various androgen suppression therapies in men with prostatic carcinoma: effects of orchiectomy, estrogen, and combination treatment with luteinizing hormone-releasing hormone agonist and flutamide. Journal of Clinical Endocrinology and Metabolism 198866 314-322. (https://doi.org/10.1210/jcem-66-2-314)

138 Eri LM, Urdal P \& Bechensteen AG. Effects of the luteinizing hormone-releasing hormone agonist leuprolide on lipoproteins, 
fibrinogen and plasminogen activator inhibitor in patients with benign prostatic hyperplasia. Journal of Urology 1995154 100-104. (https://doi.org/10.1016/S0022-5347(01)67239-2)

139 Bagatell CJ, Knopp RH, Vale WW, Rivier JE \& Bremner WJ. Physiologic testosterone levels in normal men suppress high-density lipoprotein cholesterol levels. Annals of Internal Medicine 1992116 967-973. (https://doi.org/10.7326/0003-4819-116-12-967)

140 Roelfsema F, Yang RJ \& Veldhuis JD. Estradiol does not influence lipid measures and inflammatory markers in testosterone-clamped healthy men. Journal of the Endocrine Society 20182 882-892. (https:// doi.org/10.1210/js.2018-00141)

141 Komesaroff PA, Fullerton M, Esler MD, Dart A, Jennings G \& Sudhir K. Low-dose estrogen supplementation improves vascular function in hypogonadal men. Hypertension 200138 1011-1016. (https://doi.org/10.1161/hy1101.095006)

142 Yeap BB. Sex steroids and cardiovascular disease. Asian Journal of Andrology 201416 239-247. (https://doi.org/10.4103/1008682X.122357)

143 Morselli E, Santos RS, Criollo A, Nelson MD, Palmer BF \& Clegg DJ The effects of oestrogens and their receptors on cardiometabolic health. Nature Reviews Endocrinology 201790 30F-13. (https://doi. org/10.1038/nrendo.2017.12)

144 Luders E, Gaser C, Narr KL \& Toga AW. Why sex matters: brain size independent differences in gray matter distributions between men and women. Journal of Neuroscience 200929 14265-14270. (https:// doi.org/10.1523/JNEUROSCI.2261-09.2009)

145 Ngun TC, Ghahramani N, Sánchez FJ, Bocklandt S \& Vilain E. The genetics of sex differences in brain and behavior. Frontiers in Neuroendocrinology 201132 227-246. (https://doi.org/10.1016/j. yfrne.2010.10.001)

146 Roselli CE. Neurobiology of gender identity and sexual orientation. Journal of Neuroendocrinology 201830 e12562. (https://doi. org/10.1111/jne.12562)

147 McCarthy MM. Estradiol and the developing brain. Physiological Reviews $2008 \mathbf{8 8}$ 91-124. (https://doi.org/10.1152/ physrev.00010.2007)

148 Olsen KL. Androgen-insensitive rats are defeminised by their testes. Nature 1979279 238-239. (https://doi.org/10.1038/279238a0)

149 Nugent BM, Wright CL, Shetty AC, Hodes GE, Lenz KM, Mahurkar A, Russo SJ, Devine SE \& McCarthy MM. Brain feminization requires active repression of masculinization via DNA methylation. Nature Neuroscience 201518 690-697. (https://doi.org/10.1038/nn.3988)

150 Roselli CE, Schrunk JM, Stadelman HL, Resko JA \& Stormshak F. The effect of aromatase inhibition on the sexual differentiation of the sheep brain. Endocrine 200629 501-511. (https://doi.org/10.1385/ ENDO:29:3:501)

151 Morris JM. The syndrome of testicular feminization in male pseudohermaphrodites. American Journal of Obstetrics and Gynecology 195365 1192-1211. (https://doi.org/10.1016/0002-9378(53)90359-7)

152 Matousek RH \& Sherwin BB. A randomized controlled trial of addback estrogen or placebo on cognition in men with prostate cancer receiving an antiandrogen and a gonadotropin-releasing hormone analog. Psychoneuroendocrinology 201035 215-225. (https://doi. org/10.1016/j.psyneuen.2009.06.012)

153 Taxel P, Stevens MC, Trahiotis M, Zimmerman J \& Kaplan RF. The effect of short-term estradiol therapy on cognitive function in older men receiving hormonal suppression therapy for prostate cancer. Journal of the American Geriatrics Society 200452 269-273. (https:// doi.org/10.1111/j.1532-5415.2004.52067.x)

154 Resnick SM, Matsumoto AM, Stephens-Shields AJ, Ellenberg SS, Gill TM, Shumaker SA, Pleasants DD, Barrett-Connor E, Bhasin S, Cauley JA et al. Testosterone treatment and cognitive function in older men with low testosterone and age-associated memory impairment. JAMA 2017317 717-727. (https://doi.org/10.1001/jama.2016.21044)

155 Karling P, Hammar M \& Varenhorst E. Prevalence and duration of hot flushes after surgical or medical castration in men with prostatic carcinoma. Journal of Urology 1994152 1170-1173. (https://doi. org/10.1016/S0022-5347(17)32530-2)

156 Jayasena CN, Comninos AN, Stefanopoulou E, Buckley A, Narayanaswamy S, Izzi-Engbeaya C, Abbara A, Ratnasabapathy R, Mogford J, Ng N et al. Neurokinin B administration induces hot flushes in women. Scientific Reports 20155 8466. (https://doi. org/10.1038/srep08466)

157 Taylor AP, Lee H, Webb ML, Joffe H \& Finkelstein JS. Effects of testosterone and estradiol deficiency on vasomotor symptoms in hypogonadal men. Journal of Clinical Endocrinology and Metabolism 2016101 3479-3486. (https://doi.org/10.1210/jc.2016-1612)

158 Fukami M, Tsuchiya T, Vollbach H, Brown KA, Abe S, Ohtsu S, Wabitsch M, Burger H, Simpson ER, Umezawa A et al. Genomic basis of aromatase excess syndrome: recombination- and replicationmediated rearrangements leading to CYP19A1 overexpression. Journal of Clinical Endocrinology and Metabolism 201398 E2013-E2021. (https://doi.org/10.1210/jc.2013-2520)

159 Shozu M, Sebastian S, Takayama K, Hsu WT, Schultz RA, Neely K, Bryant M \& Bulun SE. Estrogen excess associated with novel gainof-function mutations affecting the aromatase gene. New England Journal of Medicine 2003348 1855-1865. (https://doi.org/10.1056/ NEJMoa021559)

160 Santen RJ \& Simpson E. History of estrogen: its purification, structure, synthesis, biologic actions, and clinical implications. Endocrinology 2019160 605-625. (https://doi.org/10.1210/en.2018-00529)

161 Coen P, Kulin H, Ballantine T, Zaino R, Frauenhoffer E, Boal D, Inkster S, Brodie A \& Santen R. An aromatase-producing sexcord tumor resulting in prepubertal gynecomastia. New England Journal of Medicine 1991324 317-322. (https://doi.org/10.1056/ NEJM199101313240507)

162 Ham S, Meachem SJ, Choong CS, Charles AK, Baynam GS, Jones TW, Samarajeewa NU, Simpson ER \& Brown KA. Overexpression of aromatase associated with loss of heterozygosity of the STK11 gene accounts for prepubertal gynecomastia in boys with Peutz-Jeghers syndrome. Journal of Clinical Endocrinology and Metabolism 201398 E1979-E1987. (https://doi.org/10.1210/jc.2013-2291)

163 Agarwal VR, Takayama K, Van Wyk JJ, Sasano H, Simpson ER \& Bulun SE. Molecular basis of severe gynecomastia associated with aromatase expression in a fibrolamellar hepatocellular carcinoma. Journal of Clinical Endocrinology and Metabolism 199883 1797-1800. (https://doi.org/10.1210/jcem.83.5.4773)

164 Narula HS \& Carlson HE. Gynaecomastia--pathophysiology, diagnosis and treatment. Nature Reviews: Endocrinology 201410 684-698. (https://doi.org/10.1038/nrendo.2014.139)

165 Rochefort H \& Garcia M. The estrogenic and antiestrogenic activities of androgens in female target tissues. Pharmacology and Therapeutics 198323 193-216. (https://doi.org/10.1016/0163-7258(83)90013-X)

166 Braunstein GD. Gynecomastia. New England Journal of Medicine 1993 328 490-495. (https://doi.org/10.1056/NEJM199302183280708)

167 Anderson DC. Sex-hormone-binding globulin. Clinical Endocrinology 19743 69-96. (https://doi.org/10.1111/j.1365-2265.1974.tb03298.x)

168 Groth KA, Skakkebæk A, Høst C, Gravholt CH \& Bojesen A. Clinical review: Klinefelter syndrome - a clinical update. Journal of Clinical Endocrinology and Metabolism 201398 20-30. (https://doi. org/10.1210/jc.2012-2382)

169 Santi D, De Vincentis S, Scaltriti S \& Rochira V. Relative hyperestrogenism in Klinefelter syndrome: results from a meta-analysis. Endocrine 20192 1-11. (https://doi.org/10.1007/s12020-019-01850-y)

170 Russell N, Cheung A \& Grossmann M. Estradiol for the mitigation of adverse effects of androgen deprivation therapy. Endocrine-Related Cancer 201724 R297-R313. (https://doi.org/10.1530/ERC-17-0153)

171 Zoeller RT, Brown TR, Doan LL, Gore AC, Skakkebaek NE, Soto AM, Woodruff TJ \& Saal Vom FS. Endocrine-disrupting chemicals and public health protection: a statement of principles from the Endocrine Society. Endocrinology 2012153 4097-4110. (https://doi. org/10.1210/en.2012-1422) 
172 Becker D, Wain LM, Chong YH, Gosai SJ, Henderson NK, Milburn J, Stott V \& Wheeler BJ. Topical dihydrotestosterone to treat micropenis secondary to partial androgen insensitivity syndrome (Pais) before, during, and after puberty - a case series. Journal of Pediatric Endocrinology and Metabolism 201629 173-177. (https://doi. org/10.1515/jpem-2015-0175)

173 Guo W, Bachman E, Li M, Roy CN, Blusztajn J, Wong S, Chan SY, Serra C, Jasuja R, Travison TG et al. Testosterone administration inhibits hepcidin transcription and is associated with increased iron incorporation into red blood cells. Aging Cell 201312 280-291. (https://doi.org/10.1111/acel.12052)

174 Whiting DA, Olsen EA, Savin R, Halper L, Rodgers A, Wang L, Hustad C, Palmisano J \& Male Pattern Hair Loss Study Group. Efficacy and tolerability of finasteride $1 \mathrm{mg}$ in men aged 41 to 60 years with male pattern hair loss. European Journal of Dermatology 200313 150-160.

175 Bhasin S, Cunningham GR, Hayes FJ, Matsumoto AM, Snyder PJ, Swerdloff RS, Montori VM \& Task Force, Endocrine Society. Testosterone therapy in men with androgen deficiency syndromes: an Endocrine Society clinical practice guideline. Journal of Clinical Endocrinology and Metabolism 201095 2536-2559. (https://doi. org/10.1210/jc.2009-2354)

176 Wit JM, Hero M \& Nunez SB. Aromatase inhibitors in pediatrics. Nature Reviews: Endocrinology 20118 135-147. (https://doi. org/10.1038/nrendo.2011.161)
177 Carlson HE. Approach to the patient with gynecomastia. Journal of Clinical Endocrinology and Metabolism 201196 15-21. (https://doi. org/10.1210/jcem.96.9.zeg15a)

178 Grossmann M \& Matsumoto AM. A perspective on middle-aged and older men with functional hypogonadism: focus on holistic management. Journal of Clinical Endocrinology and Metabolism 2017 102 1067-1075. (https://doi.org/10.1210/jc.2016-3580)

179 Zirilli L, Maffei L, Meunier PJ, Chavassieux P, Carani C \& Rochira V. The effects of long-term raloxifene and estradiol treatments on bone in a patient with congenital aromatase deficiency. Bone 200945 827-832. (https://doi.org/10.1016/j.bone.2009.03.672)

180 Gerber GS, Zagaja GP, Ray PS \& Rukstalis DB. Transdermal estrogen in the treatment of hot flushes in men with prostate cancer. Urology 200055 97-101. (https://doi.org/10.1016/S0090-4295(99)00370-2)

181 Shozu M, Fukami M \& Ogata T. Understanding the pathological manifestations of aromatase excess syndrome: lessons for clinical diagnosis. Expert Review of Endocrinology and Metabolism 20149 397-409. (https://doi.org/10.1586/17446651.2014.926810)

182 Rochira V \& Carani C. Aromatase deficiency in men: a clinical perspective. Nature Reviews: Endocrinology 20095 559-568. (https:// doi.org/10.1038/nrendo.2009.176)

183 Handelsman DJ, Newman JD, Jimenez M, McLachlan R, Sartorius G \& Jones GRD. Performance of direct estradiol immunoassays with human male serum samples. Clinical Chemistry 201460 510-517. (https://doi.org/10.1373/clinchem.2013.213363)

Received 17 December 2018

Revised version received 4 May 2019

Accepted 14 May 2019 